\title{
Experimental Investigation of the Permeability and Mechanical Behaviours of Chemically Corroded Limestone Under Different Unloading Conditions
}

\author{
Hao $\mathrm{Li}^{1,2,3} \cdot$ Zuliang Zhong ${ }^{1,2} \cdot$ Kenneth Imo-Imo Eshiet ${ }^{4} \cdot$ Yong Sheng $^{5} \cdot$ Xinrong Liu $^{1,2} \cdot$ Dongmin Yang $^{3}$
}

Received: 2 August 2018 / Accepted: 1 September 2019 / Published online: 4 November 2019

(c) The Author(s) 2019

\begin{abstract}
This paper investigates the mechanical properties and permeability of chemically corroded rock during deep underground tunneling. Nuclear magnetic resonance tests are carried out to quantify the chemical damage of limestone samples at the microscopic scale. Coupled hydrostatic pressure-unloading tests at different unloading rates are also conducted on these chemically corroded limestone samples to investigate permeability changes and chemical effects on mechanical behaviours. Magnetic resonance imaging, $T_{2}$ spectrum distribution and porosity of the samples are obtained, and the chemical micro damage is visualized and quantified. The relationship between permeability and mechanical behaviors of the rock under hydrochemical-mechanical coupled effects is investigated. The results show that the permeability development process of the chemical corroded samples can be divided into three stages: at the first stage, the permeability initially decreases, and the second stage starts at the inflection point of the permeability curve, from where the permeability begins to increase slightly. At the third stage, the permeability of the limestone increases dramatically until the sample is ruptured. Chemical corrosion and unloading rates have a combined and significant influence on the development of micro cracks in rocks, which is the root cause of the permeability changes. A stress-permeability model is proposed to describe the permeability and stresses in chemical-corroded limestone; this can be adopted for other sedimentary rocks.
\end{abstract}

Keywords Nuclear magnetic resonance (NMR) $\cdot$ Micro damage $\cdot$ Hydrochemical-mechanical coupled effects $\cdot$ Unloading $\cdot$ Permeability

\section{List of Symbols}

NMR Nuclear magnetic resonance

MRI Magnetic resonance imaging

Dongmin Yang

D.Yang@leeds.ac.uk

Zuliang Zhong

haiou983@126.com

1 School of Civil Engineering, University of Chongqing, Chongqing 400044, China

2 National Joint Engineering Research Center for Prevention and Control of Environmental Geological Hazards in the TGR Area, Chongqing University, Chongqing 400045, China

3 School of Civil Engineering, University of Leeds, Leeds LS2 9JT, UK

4 Sustainable Energy Environmental and Educational Development (SEEED) Ltd, Sugar Land, TX 77478, USA

5 Faculty of Science and Engineering, University of Wolverhampton, Wolverhampton WV1 1LY, UK
ESP Stress-permeability model

$D_{p} \quad$ Unloading percentage

$\sigma_{\mathrm{s}} \quad$ Peak strength of the limestone samples

$\sigma_{i} \quad$ Unloading stress

$D \quad$ Damage variable

$n_{0} \quad$ The porosity of the intact sample

$n \quad$ The porosity of the sample after suffered external damage

$n_{\mathrm{r}} \quad$ The residual porosity of the sample under external stress

$k \quad$ Permeability of the sample

$Q \quad$ Flow rate

$u \quad$ Kinematic viscosity

$L \quad$ The length of the test sample

$p \quad$ Water pressure

A The cross-sectional area of the sample

a The stress sensitivity coefficient

$b \quad$ Material constant

Rate The reaction rate of calcspar

$K \quad$ The equilibrium constant 
$\Omega \quad$ The solution saturation index

$p_{1} \quad$ The density of limestone

$p_{\mathrm{c}} \quad$ The density of calcspar

$V_{\mathrm{c}} \quad$ The molar volume of the calcspar

$r \quad$ The chemical reaction equivalent parameter

$V_{\mathrm{c}} \quad$ Molar volume of the calcspar

$t \quad$ The chemical corrosion time

\section{Introduction}

Major structures such as reservoir dams, tunnels and nuclear power plants are constructed in/on rock mass. Engineering rock masses are often surrounded by water, containing complex chemical ions with different $\mathrm{pH}$ values (Jeffery and Hutchison 1981). The chemical environment can cause great changes at the microscopic level in rock, such as an increase in porosity or micro-structure weakening (Kawakata et al. 1999; Sato and Obara 2017; Grgic et al. 2013). These changes may cause macroscopic degradation of mechanical properties (Zhou et al. 2015; Hu et al. 2012; Rohmer et al. 2016) and an acceleration of the failure process, leading to further decrease in mechanical characteristics and the tendency towards geological disasters such as landslides and earthquakes (Steefel and Van Cappellen 1990; Croizé et al. 2010). There are several studies on the mechanical characteristics of rocks under chemical-mechanical coupled conditions (Chai et al. 2014; Chen et al. 2004; Feng et al. 2004; Feng and Ding 2007; Gaus 2010; Wojtacki et al. 2017). However, previous studies are mainly conducted at the macroscopic scale and focus on rock under continuous loading, such as uniaxial loads or triaxial compression.

During excavations in underground constructions, external stresses generate micro cracks inside the rock near the working surface, which can be a significant factor affecting the degradation of its mechanical properties (Friedman 1975). These cracks also enhance the path of chemical ions transfer and the permeability of rocks, so that the chemical reactions between the rock material and chemical ions are accelerated (Cui and Fall 2015), which also hastens changes in the mechanical properties of the rock. The damaged zone is always near the excavation surface of underground constructions, and can be called "the excavation damaged zone (EDZ)" (Tsang et al. 2005; Kruschwitz and Yaramanci 2004). The fracturing process both at the micro- and macroscopic level and stress redistribution, etc., may take place in the EDZ during the excavation of rocks, resulting in changes in its permeability and mechanical behavior. Permeability also has a significant and attenuating influence on mechanical properties of rock masses (Sulem et al. 2007). Thus, chemical effects on mechanical properties and permeability characteristics of rock under external loading conditions are complex.

EDZ occurs in almost all underground structures, e.g. tunnels and nuclear waste storage tanks. The mechanical properties of the rock in EDZ and its permeability are important research areas in different geological engineering applications such as nuclear waste storage (Zhu and Bruhns 2008), gas injection (Rutqvist and Tsang 2002; Bouc et al. 2009; Gaus 2010; Gaus et al. 2005), geological disasters (Wibberley and Shimamoto 2005) and fluid modeling (Cappa and Rutqvist 2011; Rutqvist 2011; Zhang et al. 2011). For example, the EDZ in nuclear waste storage may provide a pathway for chemical water flow which transports radioactive wastes to other places thereby accelerating the process of degradation of the mechanical properties of surrounding rocks (Zhu and Bruhns 2008). Moreover, the permeability and mechanical characteristics of the rocks is important for $\mathrm{CO}_{2}$ migration predictions and geologic carbon sequestration (GCS) site (Rutqvist and Tsang 2002).

During excavation in underground construction works such as deep-buried tunnels or caverns, the radial stress (corresponding to the confining pressure in lab tests) of the surrounding rock mass near the working face always suffered a cycle of loading and unloading conditions. These loading and unloading conditions could lead to EDZ, or even failure or the yielding of the surrounding rock masses, such as rock burst, bulking, spalling or landslide (Martin et al. 2003). Lots of studies have demonstrated that mechanical characteristics of rocks are significantly influenced by loading rates, stress path, stress and loading history, and chemical corrosion ( $\mathrm{Ju}$ et al. 2019; Kaiser et al. 2001; Martin et al. 1999b; Cantieni and Anagnostou 2009; Chen et al. 2016b). According to continuous mechanism theories (Martin et al. 1999a; Westergaard 1952; Vutukuri 1974), changes in the internal variables of the rock under unloading conditions have a great effect on its strength, deformability performances and failure characteristics. Some lab tests also demonstrate that internal variables, such as unloading rate or unloading point, are significantly associated with the mechanical characters of the rocks (Shalabi 2005; Sharifzadeh et al. 2013; Zhang et al. 2010; Qiu et al. 2010; Liu and Li 2011). In tunnel constructions, unloading characters, such as unloading point or unloading rate, have a close relationship with construction footage and construction timing, which could affect the stability of the tunnel.

In laboratory tests, the triaxial unloading tests, in which the axial stress $\sigma_{1}$ increases or remain unchanged after the unloading point, while the confining stress $\left(\sigma_{3}\right)$ decreases, are used to simulate the unloading phenomenon during tunneling (Brady and Brown 2013; Xue et al. 2017). The influence of unloading-confining pressure on the mechanical properties of rock has been investigated through experimental tests (He et al. 2010; Huang et al. 2001; Lemaitre and Desmorat 2005; Xie and He 2004; Moradian et al. 2016; Munoz et al. 2016; Adushkin et al. 2016). However, studies about unloading tests rarely take chemical environments into consideration, and the microscopic-scale investigations of chemically corroded rocks under states 
of unloading-confining pressure are few. The mechanical behavior of chemically corroded rocks near the excavation surface of tunnels has not been clearly understood.

Moreover, as discussed before, external stresses generate micro cracks inside the rock, which could enhance the path of chemical ions transfer thus amplifying the chemical effects on mechanical characteristics degradation. The challenge in understanding the relationship between permeability and mechanical properties as well as the relationship between micro damage and permeability of the rocks is long-standing. Some studies have proposed relationships between hydro-mechanical properties, permeability and rock fracturing (Liu et al. 2009; Chen et al. 2016a; Zhang et al. 2015; Li et al. 2014; Zou et al. 2016). Other studies have investigated and predicted permeability as well as its relationship with external loads or porosity of rocks. Examples of this include a seepage test on jointed sandstone samples under different confining pressures, conducted by Wong et al. (2013); investigations by Zhang et al. (2015) to establish stress-permeability, stress-porosity and permeability-porosity relationships in rock; investigations by Meng et al. (2012) to determine the effects of unloading on permeability of water and changes in mechanical properties of rock based on a coupled thermal-hydromechanical test.

Although previous studies have contributed to the understanding of permeability and its relationship with the mechanical properties of intact rock under external loads, they are seldom about chemical effects on both mechanical properties and permeability of rock during unloading, at the microscopic scale. In this study, hydrostatic tests are conducted involving chemically corroded limestone samples under different unloading rates of confining pressure. The NMR system is used to obtain magnetic resonance imaging (MRI), $T_{2}$ values (transverse relaxation time distribution, which depends on the size of water-saturated pores) and porosities of the chemically corroded limestone samples. The test data are used to analyze the mechanism for the change of permeability in chemically corroded limestone under unloading conditions and the relationship between the permeability and microstructure of limestone. Finally, a stress-permeability (ESP) model is proposed to correlate permeability with stresses and used to predict relationships between both variables in chemically corroded limestone.

\section{Sample Information and Experimental Setup}

\subsection{Limestone Samples and Chemical Solutions}

Limestone was used as the test sample in this experiment. Samples were collected from a tunnel construction site in Chongqing, called Jinyun Mountain Tunnel, in southwest China, as shown in Fig. 1a. Jinyun Mountain Tunnel is in

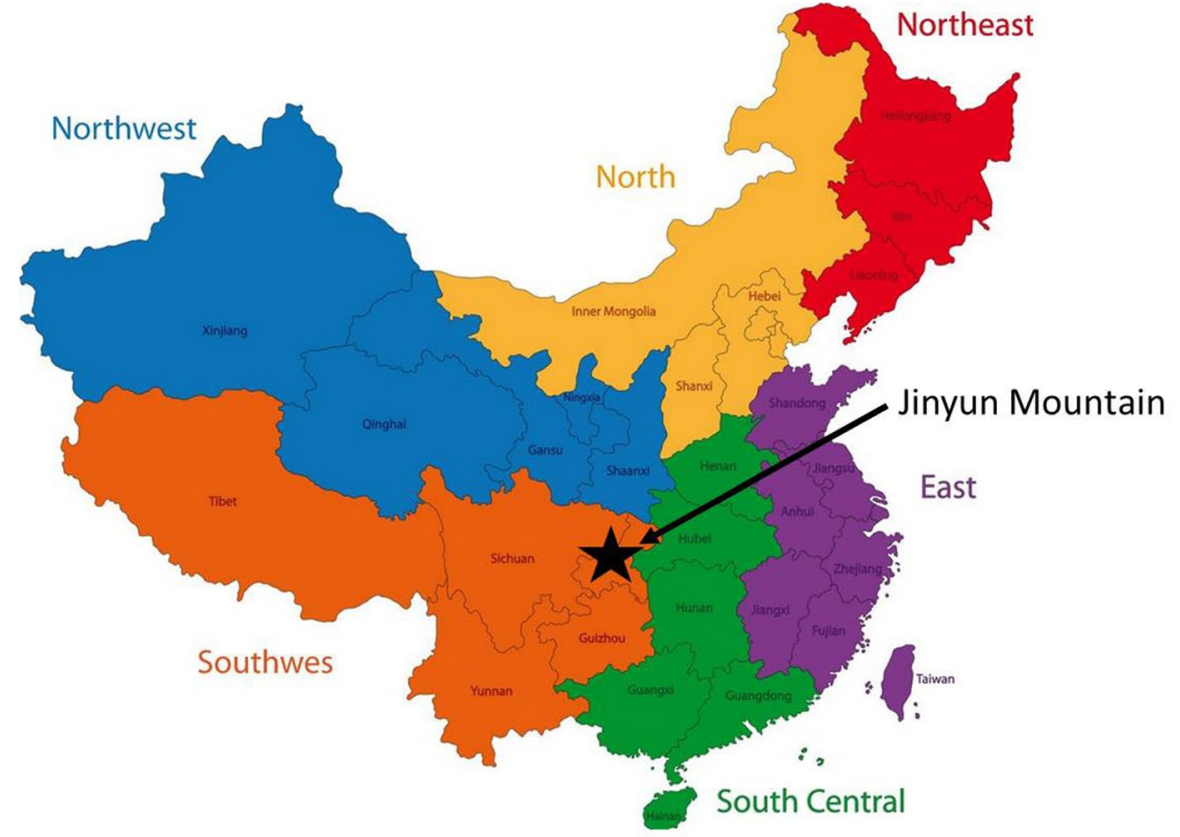

(a) Location of Jinyun Mountain

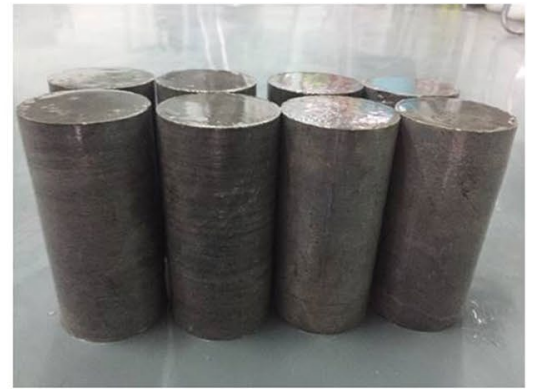

(b) Test samples

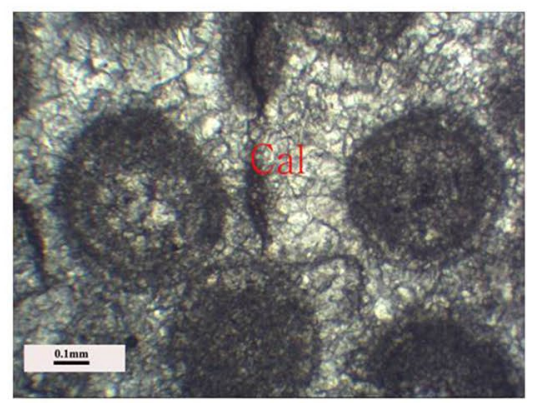

(c) Microscope image of the sample: Cal, calcspar.

Fig. 1 Location and micro structure of the sample 
Jinyun Mountain, which is located in the low-mountain hilly area in Sichuan Basin, dominated by sedimentary rocks such as limestone. Jinyun Mountain Tunnel is near Yangtze River and Jialing River. It starts at K38 +616 and ends at $\mathrm{K} 42+270$ with a total tunnel length of $3654 \mathrm{~m}$.

All the limestone samples were selected at Jinyun Mountain from a single rock block without macroscopic cracks and prepared carefully to minimize the development of micro cracks before mechanical testing including triaxial and unloading confining pressure tests. X-Ray diffraction (XRD) analysis was used to determine the composition of the limestone samples consisting of $90 \%$ calcspar and quartz, and $10 \%$ cements and accessory minerals, including $\mathrm{Fe}_{2} \mathrm{O}_{3}$ and $\mathrm{O}_{2}$. The limestone is oolithic, as shown in Fig. 1c. A polishing machine was used to cut the limestone samples into smooth-ended cylindrical shapes with a length of $100 \mathrm{~mm}$ and a diameter of $50 \mathrm{~mm}$ (Fig. 1b).

Water was collected from the same construction site and analyzed. The $\mathrm{pH}$ value of the water is 6.5 , and the main ions are $\mathrm{Na}^{+}, \mathrm{Ca}^{2+}, \mathrm{Mg}^{2+}, \mathrm{SO}_{4}^{2-}, \mathrm{Cl}^{-}$and $\mathrm{HCO}^{-}$. To simplify the experimental study, a $\mathrm{Na}_{2} \mathrm{SO}_{4}$ solution was chosen as a substitute for the complex ionic composition of the water. To accelerate the chemical reaction without affecting the trend in corrosion and the basic chemical reaction mechanism, the hydrogen ion, $\mathrm{H}^{+}$, in the chemical solution in the laboratory test was augmented to be higher than that obtainable in nature (Jeffery and Hutchison 1981; Lasaga 1984; Seto et al. 1997). Thus, two $\mathrm{pH}$ values ( 3 and 5 ) of the $\mathrm{Na}_{2} \mathrm{SO}_{4}$ solution were used and all initial concentrations of the chemical solutions were $0.01 \mathrm{~mol} \mathrm{~L}^{-1}$, as shown in Table 1 .

\subsection{Experimental Measurement System}

The NMR system was used to determine the micro-properties of the limestone samples, including $T_{2}$ spectrum distributions, magnetic resonance imaging (MRI), as well as porosity. The system (Fig. 2a) measures the signal intensity of hydrogen atoms in the fully water-saturated rock, then outputs transverse the relaxation time distribution $\left(T_{2}\right.$ spectrum).

All mechanical and permeability tests were conducted using a rock testing system, as shown in Fig. 2b; the testing cell is sketched in Fig. 2c, e. The pressure in the cell of the rock testing machine was generated by an oil pressure apparatus. All the samples were put into polyolefin tubes $(2 \mathrm{~mm}$ in thickness) in the testing cell (Fig. 2c, d) of the system prior to the tests. To improve the accuracy of permeability measurements, two groove spacers with several pores were placed in the upper and bottom surface of the rock sample, as shown in Fig. 2d.

Stresses (axial stress, confining stress, etc.) were measured and recorded by computer in the rock testing system. The axial strain was measured by two sensors (no. 1 and no. 2) (Fig. 2e), which were fixed between the bottom and top surfaces of the sample inside the cell. The radial strain and the volumetric strain were measured by three chains and axial strain was measured by two sensors (Fig. 2e). The chemical solution or distilled water was steadily injected from the bottom of the sample with the outflow occurring at the top surface. During the tests, the axial permeability was measured by Darcy's law, expressed as follows:

$k=\frac{u Q l}{A \Delta p}$,

where $Q$ is the flow rate, $u$ is the kinematic viscosity, $L$ is the length of the test sample, $\Delta p$ is the pressure difference between the upstream and downstream end of the sample and $A$ is the cross-sectional area of the sample.

\subsection{Experimental Setup and Test Procedure}

In this test, the permeability evolution of chemically corroded limestone is investigated through the whole loading and unloading processes. The permeability characteristics

Table 1 Groups of limestone samples

\begin{tabular}{|c|c|c|c|c|c|c|c|c|c|}
\hline $\begin{array}{l}\text { No. of } \\
\text { sample }\end{array}$ & $\mathrm{pH}$ value & $D_{\mathrm{p}}(\%)$ & $\begin{array}{l}\text { Permeability } \\
\text { stress (MPa) }\end{array}$ & $\begin{array}{l}\text { Unloading } \\
\text { rates }\end{array}$ & No. of sample & $\mathrm{pH}$ value & $D_{\mathrm{p}}(\%)$ & $\begin{array}{l}\text { Permeability } \\
\text { stress (MPa) }\end{array}$ & Unloading rates \\
\hline A-1 & 3 & 100 & 4 & - & $\mathrm{C}-2$ & 3 & 70 & 4 & 0.03 \\
\hline A-2 & 5 & 100 & 4 & - & C-3 & 3 & 70 & 4 & 0.05 \\
\hline A-3 & $\begin{array}{l}\text { Distilled } \\
\text { water }\end{array}$ & 100 & 4 & - & D-1 & 5 & 70 & 4 & 0.01 \\
\hline A-4 & Intact & 100 & 4 & - & D-2 & 5 & 70 & 4 & 0.03 \\
\hline B-1 & Intact & 70 & 4 & 0.01 & D-3 & 5 & 70 & 4 & 0.05 \\
\hline B-2 & Intact & 70 & 4 & 0.03 & E-1 & Distilled water & 70 & 4 & 0.01 \\
\hline B-3 & Intact & 70 & 4 & 0.05 & E-2 & Distilled water & 70 & 4 & 0.03 \\
\hline C-1 & 3 & 70 & 4 & 0.01 & E-3 & Distilled water & 70 & 4 & 0.05 \\
\hline
\end{tabular}




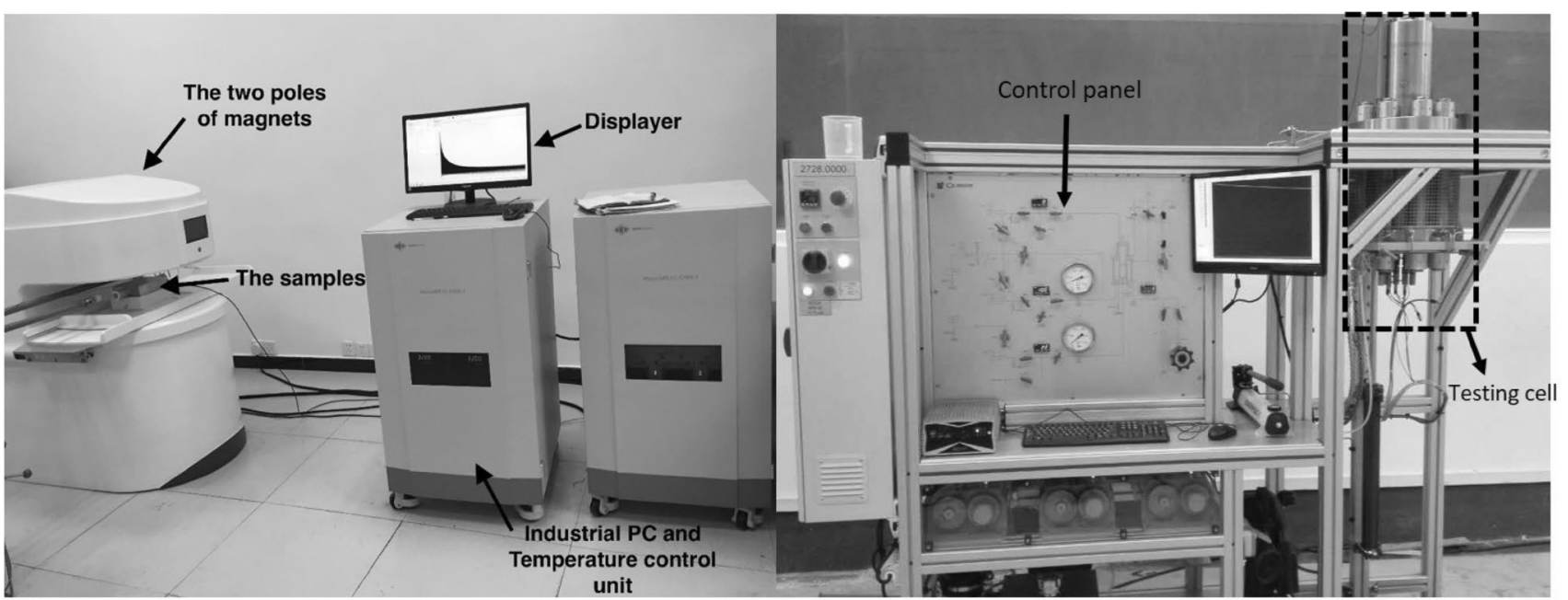

(a) NMR system

(b) Rock testing machine

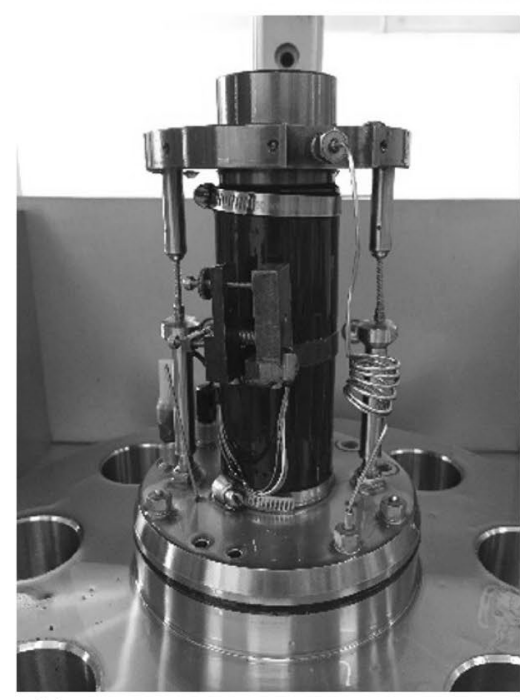

(c) Testing cell of the rock testing system

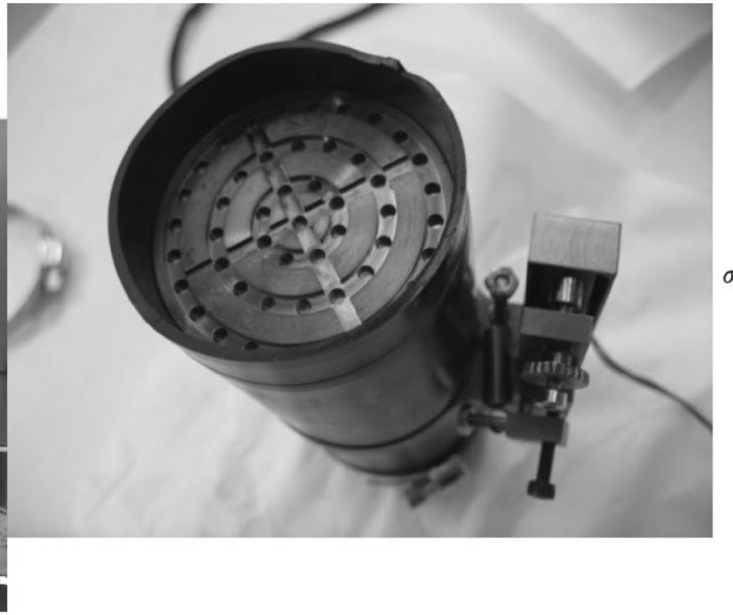

(d) Permeability spacer in testing cell

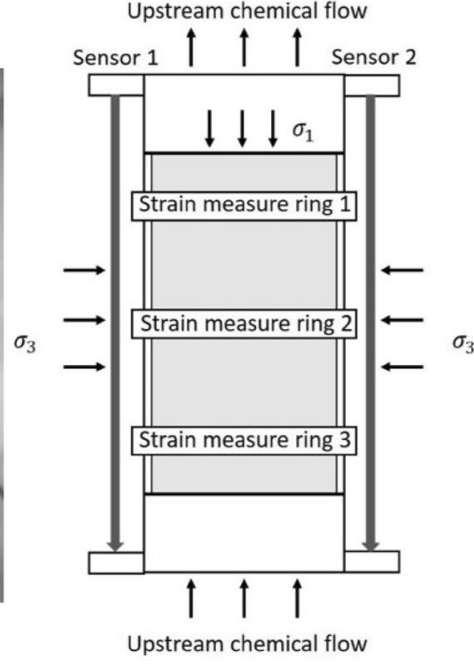

(e) Sketch of the testing cell

Fig. 2 Testing system

of samples under an unloading confining pressure are compared with those under a constant confining pressure.

First, samples were fully saturated using a vacuum saturation device. After saturation for $24 \mathrm{~h}$ in vacuum saturation machine, samples were tested by NMR system to obtain its porosity and $T_{2}$ distribution. Samples with similar porosity distribution were selected in this study. Then these samples were categorized into five groups to be immersed for 60 days, either in distilled water or $\mathrm{Na}_{2} \mathrm{SO}_{4}$ solutions with two $\mathrm{pH}$ values ( 3 and 5). When the samples reached the designed corrosion period, NMR tests were conducted to analyze porosity changes. After the NMR tests, the samples were put into the testing cell of the rock testing machine (Fig. 2). The loading and unloading paths were designed based on stress redistribution characteristics, as shown in Fig. 3.
To simulate the hydrostatic pressure condition of the rock masses during tunneling, the same value (10 MPa) for the confining pressure and axial stress was firstly loaded. Then, the $\mathrm{Na}_{2} \mathrm{SO}_{4}$ solution or distilled water was injected from the bottom of the sample with a pressure of $4 \mathrm{MPa}$. This is the first stage of the test, corresponding to the loading path $\mathrm{O}-\mathrm{A}$ in Fig. 3. When the solution starts to flow out from the upper face of the sample, the test comes to the second stage. The axial stress was loaded at a rate of $0.02 \mathrm{~mm} \mathrm{~min}^{-1}$ until reaching the unloading point of the test, while the confining pressure and flow pressure were maintained at constant values. This is the second stage of the test, which corresponds to the loading path A-B in Fig. 3.

The unloading point $\mathrm{B}$, in stage 2 , is defined by the unloading percentage, $D_{\mathrm{p}}$, which can be calculated as follows: 


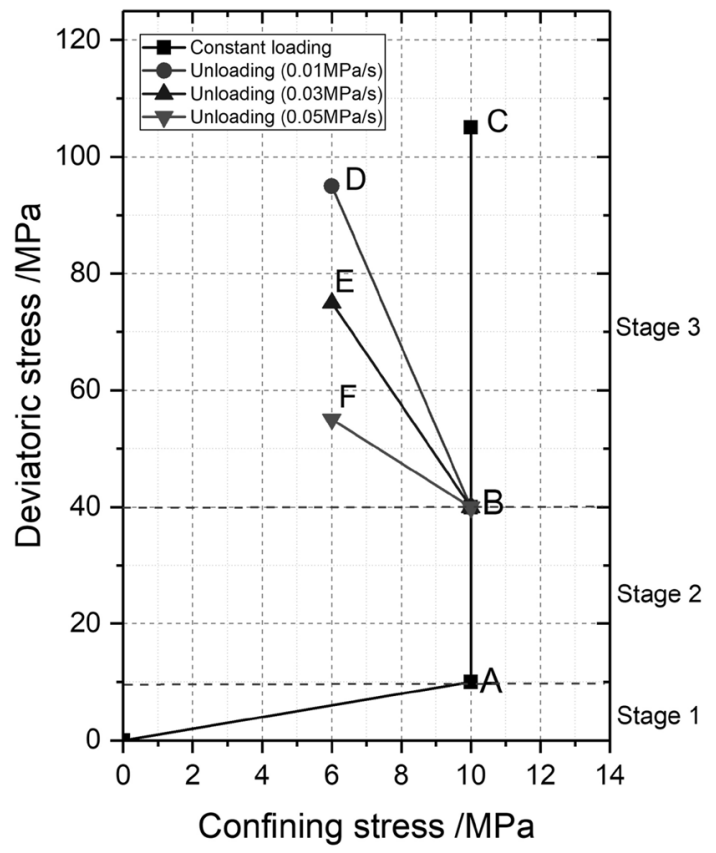

Fig. 3 Illustration of the loading and unloading paths

$D_{\mathrm{p}}=\frac{\sigma_{\mathrm{i}}}{\sigma_{\mathrm{s}}} \times 100 \%$,

where $\sigma_{\mathrm{s}}$ is the peak strength of the initial samples and $\sigma_{\mathrm{i}}$ is unloading stress for a designed test.

The loading percentage $D_{\mathrm{p}}$ in this test is $70 \%$ of the corresponding peak strength of the samples; thus, the loading stress at the unloading point $\mathrm{B}$ can be calculated based on Eq. (2):

$\sigma_{\mathrm{i}}=D_{\mathrm{p}} \times \sigma_{\mathrm{s}}$,

To obtain the unloading point, which is fixed by the unloading percentage $\left(D_{\mathrm{p}}\right)$, the peak strength $\left(\sigma_{\mathrm{s}}\right)$ of the sample in each chemical condition (Table 1) should be tested. Thus, the triaxial test (without unloading stage) was firstly conducted: after the loading path $\mathrm{A}-\mathrm{B}$, the axial stress was loaded at a rate of $0.02 \mathrm{~mm} \mathrm{~min}^{-1}$ until the sample ruptured. This corresponds to loading path A-B-C, and $\sigma_{\mathrm{s}}, D_{\mathrm{p}}$ will be obtained, so that by using Eq. (3), the unloading stress $\left(\sigma_{\mathrm{i}}\right)$ of the limestone sample in each group can be calculated.

Then, the unloading tests were conducted: the initial loading path in each case follows the same path: O-A-B. At point $\mathrm{B}$, the confining pressure was gradually unloaded, while the axial loading was simultaneously applied the same rate of $0.02 \mathrm{~mm} \mathrm{~min}^{-1}$ until the sample was ruptured. Three unloading rates of the confining pressure were chosen: $0.01 \mathrm{MPa} \mathrm{s}^{-1}$ (B-D path), $0.03 \mathrm{MPa} \mathrm{s}^{-1}$ (B-E path) and $0.05 \mathrm{MPa} \mathrm{s}^{-1}$ (B-F path) (Huang and Huang 2008; Qiu et al. 2010). During all tests, the solution flow rate at the outlet was measured continuously during the loading process.

\section{Results Analysis and Discussion}

\subsection{Micro- damage Caused by Chemical Effects}

Microscopic structure changes, including discontinuities growth, porosity changes and skeleton softened by water, etc., are the root cause of the mechanical properties degradation and permeability changes of the rocks. Damage may cause properties changes in rocks, e.g. peak strength, deformation characters, elastic modulus, permeability as well as acoustic emission parameters, etc. (Kirby 1984; Lasaga 1984). To investigate and calculate the damage caused by chemical effects and establish a damage theory for these chemically corroded rock, the definition and choice of damage variable has to be addressed.

A reasonable damage variable of the chemical corroded rocks should meet the following requirements: (1) it has distinct physical meaning; (2) it can be measured easily and applied in engineering conveniently; (3) its evolution law coincides well with the actual degradation process of material; (4) it can take the initial damage into account (Lasaga 1984; Jeffery and Hutchison 1981; Lafrance et al. 2016; Seto et al. 1997). Thus, to quantify the micro-damage, porosity is selected as the parameter to define the damage variable, $D$. Damage rates can be expressed as (Kachanov 1999):

$D=\frac{n-n_{0}}{1-n_{0}}$

where $D$ is the damage rate, $n_{0}$ is the porosity of the intact sample, and $n$ is the porosity of the sample after external damage, such as chemical corrosion or loads.

$T_{2}$ spectrum distribution, porosity and MRI (which is the inner section images of the limestone samples), are obtained through NMR tests. The $T_{2}$ spectrum distribution and MRI of the intact sample (A-1), water soft sample (D-1) and samples corroded by chemical solution (B-1 and C-1) are shown in Fig. 4, as an example, similar trends are found in other groups. The signal strength of the $T_{2}$ spectrum depends on the size of water-saturated pores. The area between the curve and the horizontal axis is the $T_{2}$ spectrum area, which has a close relationship with porosity and pore size distribution of the rock, i.e., the porosity increases with the $T_{2}$ spectrum area and the peak point of the curve increases when the pore size increase. Moreover, the bright areas in MRI correspond to pores inside the limestone samples, i.e., an increase in the brightness and the number of white points indicates an increase in porosity.

The $T_{2}$ spectrum distribution for limestone sample has three peaks, as shown in Fig. 4. The left peak and the middle peak indicate small pores and the right indicates 


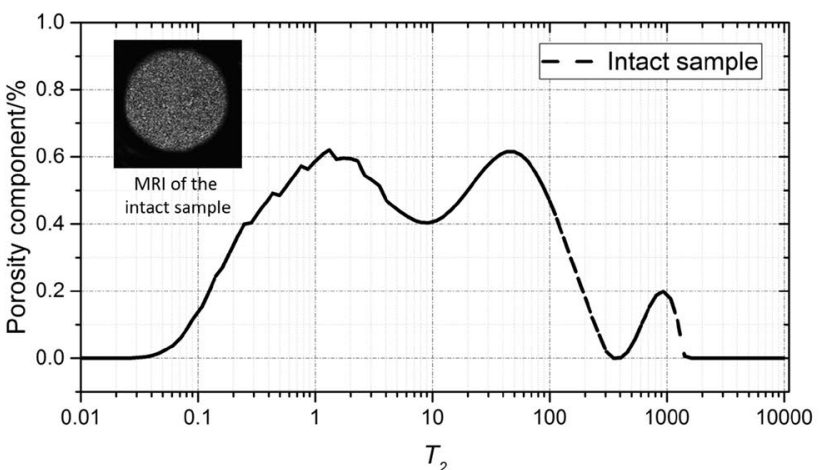

(a)

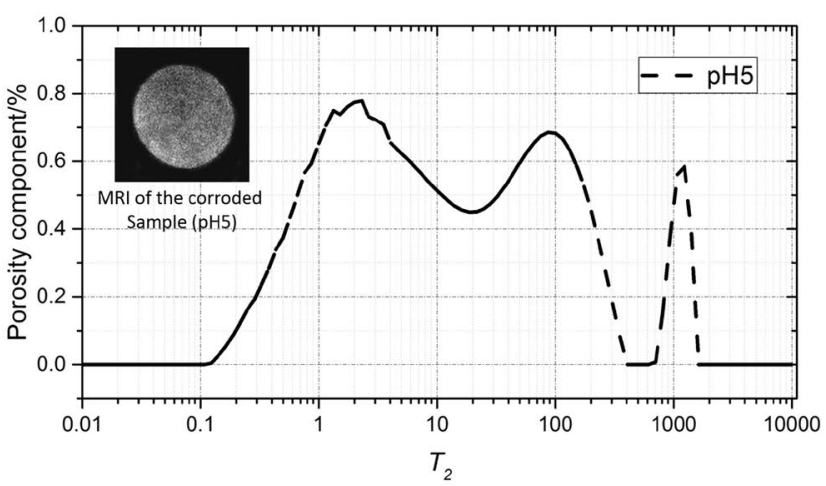

(c)

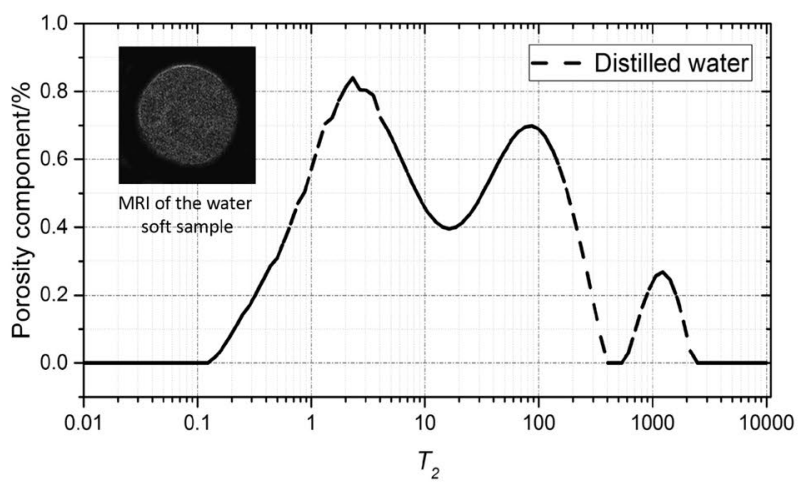

(b)

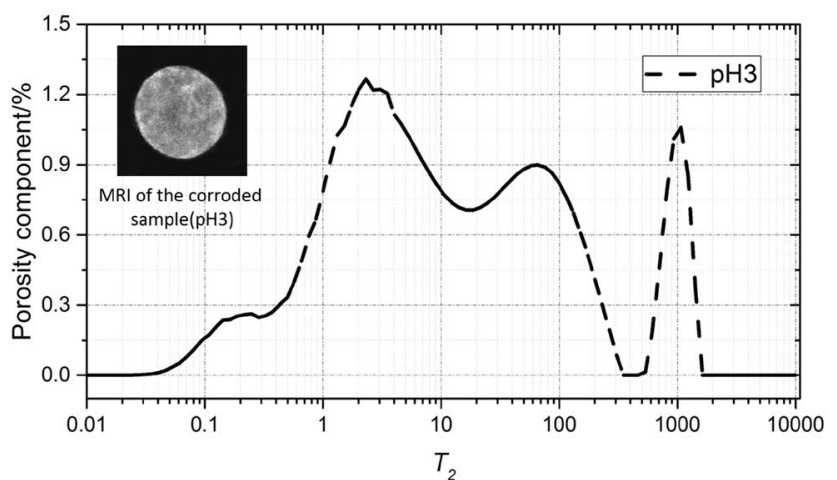

(d)

Fig. $4 T_{2}$ spectrum distribution and MRI of limestone samples

bigger pores. It can be observed that after limestone samples are immersed in a chemical (acid) solution or distilled water, there is an increase in the $T_{2}$ spectrum area and a noticeable change in the curve shape. Also, the MRI of the chemical corroded sample becomes brighter and clearer, which indicates increasing porosity inside the sample. The largest change of $T_{2}$ spectrum is found in samples immersed in solution with $\mathrm{pH} 3$ values, while the smallest spectrum change occurs in samples immersed in distilled water. Porosity changes of the limestone samples are listed in Table 2.
Using Eq. (1), the micro damage variable, $D$, can be specified, which is shown in Fig. 5. It can be observed that the micro damage of the limestone samples corroded by pH3 solution (group C, including sample no. C-1, C-2 and $\mathrm{C}-3$ ) are always greater than other solutions, which is 0.017 , $0.016,0.018$, respectively; micro-damage smallest in samples immersed in distilled water (group E, including sample no. E-1, E-2 and E-3), which is 0.0009, 0.0004 and 0.0005, respectively. This is due to the chemical corrosion.

The mechanism of the micro structure changes of the rocks under chemical effects lies in the corrosive action caused by the chemical ions inside the water, which will

Table 2 Limestone samples porosity change after chemical corrosion

\begin{tabular}{|c|c|c|c|c|c|c|c|}
\hline No. of samples & Initial porosity & Corrosion porosity & Increment $(\%)$ & No. of samples & Initial porosity & $\begin{array}{l}\text { Corrosion } \\
\text { porosity }\end{array}$ & Increment (\%) \\
\hline B-1 & 5.42 & Sample in air & - & D-1 & 5.40 & 6.12 & 13.33 \\
\hline B-2 & 5.46 & Sample in air & - & D-2 & 5.38 & 6.08 & 13.01 \\
\hline B-3 & 5.39 & Sample in air & - & D-3 & 5.41 & 6.25 & 15.52 \\
\hline $\mathrm{C}-1$ & 5.32 & 6.94 & 30.45 & E-1 & 5.33 & 5.42 & 1.68 \\
\hline $\mathrm{C}-2$ & 5.39 & 6.99 & 29.68 & E-2 & 5.37 & 5.38 & 0.75 \\
\hline C-3 & 5.35 & 7.12 & 33.08 & E-3 & 5.39 & 5.44 & 0.93 \\
\hline
\end{tabular}




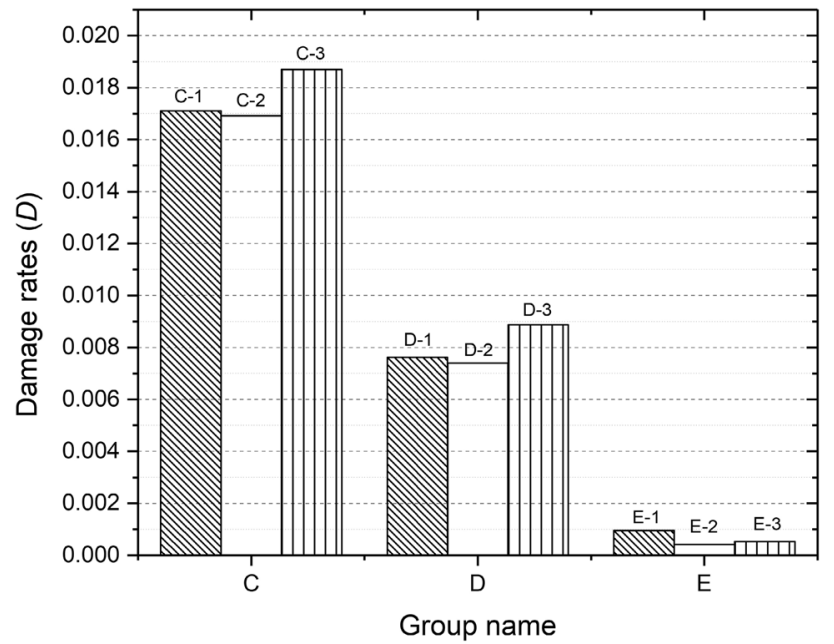

Fig. 5 Damage rates $(D)$ of the limestone samples

weaken the skeleton of the rocks and corrodes the mineral particles, eventually leading to a change in the mechanical properties of corroded rock. With the help of XRD analysis, the composition of the limestone samples includes oolite, calcite, quartz, cement, bioclastic and metal minerals, including iron oxide and silicon dioxide. The mineral components of limestone samples easily react with acid ions, $\mathrm{H}^{+}$. Moreover, some of these mineral components, such as cement, calcite, can soften or be dissolved in water, which cause the skeleton of the rock to become softer.

The main chemical reactions can be expressed as follows:

$\mathrm{CaCO}_{3}+2 \mathrm{H}^{+} \rightarrow \mathrm{Ca}^{2+}+\mathrm{H}_{2} \mathrm{O}+\mathrm{CO}_{2} \uparrow$,

The reaction of iron oxide is:

$\mathrm{Fe}_{2} \mathrm{O}_{3}+6 \mathrm{H}^{+} \rightarrow 2 \mathrm{Fe}^{3+} 3 \mathrm{H}_{2} \mathrm{O}$.

The main mineral composition of quartz is $\mathrm{SiO}_{2}$, the reaction in distilled water is:

$\mathrm{SiO}_{2}+2 \mathrm{H}_{2} \mathrm{O} \rightarrow \mathrm{H}_{4} \mathrm{SiO}_{4}$.

\subsection{HydroChemical-Mechanical Effects on Permeability Changes of the Sample}

The permeability changes during the whole loading and unloading process were obtained during the test, and the relationship between axial strain and permeability of the corroded limestone samples (pH3) subjected to unloading conditions is shown in Fig. 6a, in comparison to samples softened with water, shown in Fig. $6 \mathrm{~b}$, due to the trends of

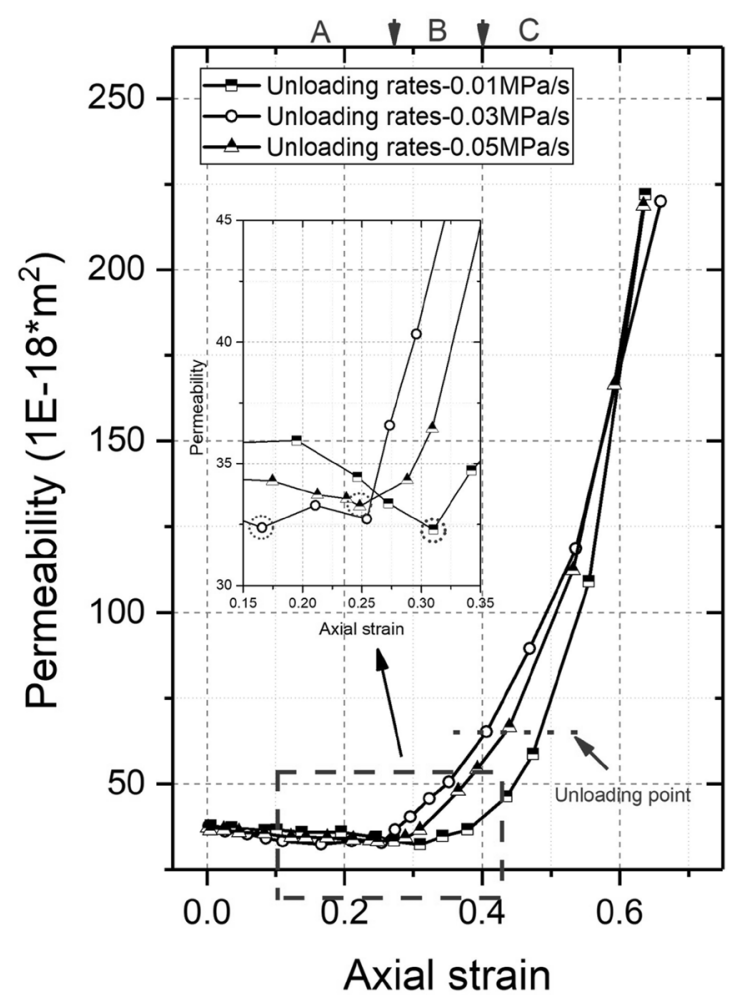

(a) Samples corroded by $\mathrm{pH} 3$ solution

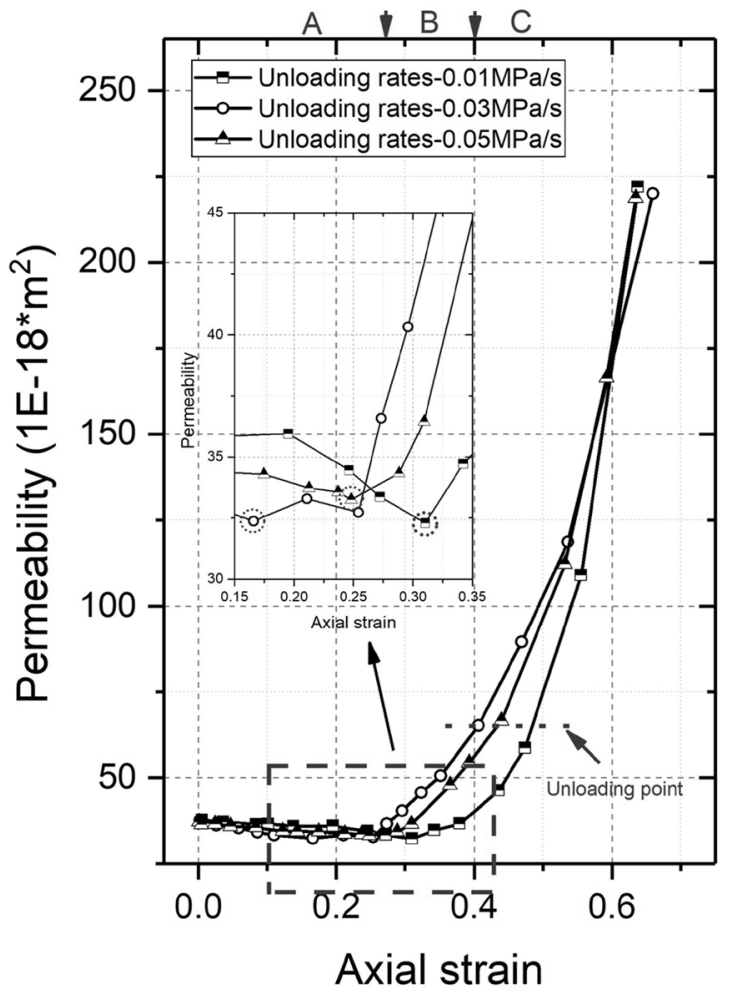

(b) Samples soften by distilled water

Fig. 6 Permeability vs axial strain of the limestone sample (A: stage 1 of the permeability; B: stage 2 of the permeability; C: stage 3 of the permeability) 
permeability evolution and its relationship with the mechanical properties of all groups of the limestone samples are similar.

The evolution of permeability in chemically corroded limestone samples can be divided into three stages, which is observed from Fig. 6. In the first stage, the permeability initially decreases with increasing deviatoric loads. The second stage starts at the inflection point of the permeability curve, which are enlarged in Fig. 6a, from where the permeability begins to increase slightly with increasing deviatoric stress. The second evolution stage is relatively short and the permeability of the sample during this period increases slightly and gradually. In the third stage, the permeability of the limestone increases dramatically until the sample ruptures. The permeability of all samples during these three stages are shown in Table 3.

From Fig. 6 and Table 3, the following can also be observed: Firstly, under the same unloading rates, the permeability of limestone samples which are corroded by the pH 3 solution are always greater than those of water-softened and intact samples. Water-softened samples have the lowest permeability. Secondly, the permeability of chemically corroded limestone samples is much more sensitive to unloading rates than water-softened and intact samples. This is because micro structural changes, including micro crack development and pore alteration caused by loading conditions, have significant effects on rock permeability. Micro cracks are more easily formed inside chemically corroded rocks. Thirdly, there are inflection points noted in red in the enlarged diagrams in Fig. 6. The inflection points are very important for permeability analyses, which are useful for investigating damage effects caused by the environment, such as the impact of chemical conditions and stress history on rock permeability and porosity (Kwon et al. 2004). The inflection points shown in Fig. 6 are the thresholds of the permeability evolution under unloading condition; before this point, the permeability decreases slightly, and after that begins to increase. The inflection points indicate the samples are already fully compacted; after these points, micro cracks begin to form some interconnections amongst them ( $\mathrm{Li}$ et al. 2018). The mechanism governing changes in the permeability of chemically corroded limestone samples under external stress is discussed in Sect. 3.3 .

\subsection{The Relationship Between the Mechanical Behavior and the Micro Damage of Limestone Under Hydrochemical-Mechanical Conditions}

Beyond a certain threshold, external stresses generate micro cracks, which enhance the path for the transfer of chemical ions and the permeability of the rock. Chemical reactions between the rock material and chemical ions are therefore accelerated. With increased permeability and chemical effect, the rock matrix is softened and there is a degradation of its mechanical properties (Alonso et al. 2013; Chai et al. 2014; Feng and Ding 2007). Porosity-strain and stress-strain curves (calculated by Eq. 1) for $\mathrm{pH} 3$ - and $\mathrm{pH}$ 5-solution samples, and water-soft samples are shown in Fig. 7a-c. T2 distribution and MRI (illustrating the porosity of the inner section of the limestone sample) for chemically corroded samples (pH 3) are shown, as an example, in Fig. 7d, e. Samples of other pHsolutions are not shown because their damage evolution is similar.

Under the effect of external compressive stresses the micro damage of limestone can be divided into four stages (Li et al. 2018), as shown in Fig. 7a-c, which also has a close relationship with the permeability changes of the rock sample. Micro pores in limestone are compacted initially, resulting in a reduction in permeability (Fig. 6). As the external stress increases, there is an emergence of new micro cracks. At a later stage, some micro cracks intersect and connect with each other, which contribute to permeability increase. With further increase in external loading, these micro cracks propagate and coalesce, and some develop into macro cracks, gradually forming shear zones, which generate localized preferential paths for fluid flow. At this point, permeability increases dramatically to its maximum.

Based on these micro damage development processes, peak strength and failure model of the samples are also influenced by chemical effects. Chemical corroded samples are also more sensitive to external stress: the micro damage develops faster in samples immersed in the $\mathrm{pH} 3$ solution

Table 3 Permeability of the limestone samples

\begin{tabular}{|c|c|c|c|c|c|c|c|}
\hline No. of sample & $\begin{array}{l}\text { Initial perme- } \\
\text { ability }\end{array}$ & $\begin{array}{l}\text { Permeability at } \\
\text { inflection point }\end{array}$ & $\begin{array}{l}\text { Rupture per- } \\
\text { meability }\end{array}$ & No. of sample & $\begin{array}{l}\text { Initial perme- } \\
\text { ability }\end{array}$ & $\begin{array}{l}\text { Permeability at } \\
\text { inflection point }\end{array}$ & $\begin{array}{l}\text { Rupture } \\
\text { perme- } \\
\text { ability }\end{array}$ \\
\hline C-1 & 75.2 & 56.3 & 270.5 & D-3 & 55.9 & 42.6 & 228.6 \\
\hline $\mathrm{C}-2$ & 74.3 & 55.9 & 210.4 & E-1 & 44.3 & 39.2 & 225.4 \\
\hline $\mathrm{C}-3$ & 70.5 & 55.3 & 202.3 & E-2 & 43.6 & 38.9 & 223.5 \\
\hline D-1 & 54.4 & 42.3 & 230.5 & E-3 & 45.1 & 39.4 & 223.8 \\
\hline D-2 & 56.2 & 36.2 & 226.4 & & & & \\
\hline
\end{tabular}




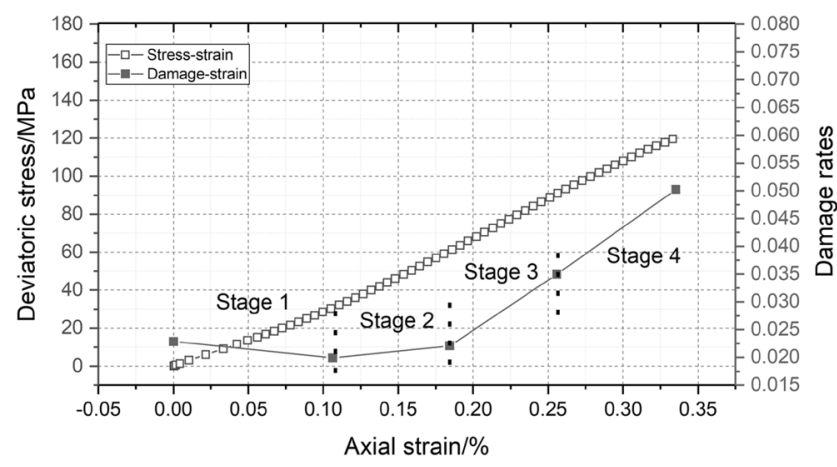

(a) Micro damage-strain and stress-strain curves of sample (pH3)

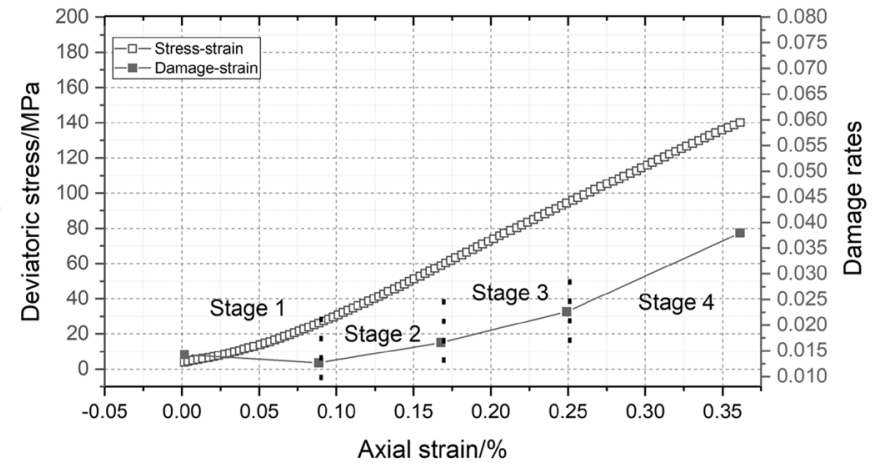

(b) Micro damage-strain and stress-strain curves of sample (pH5)

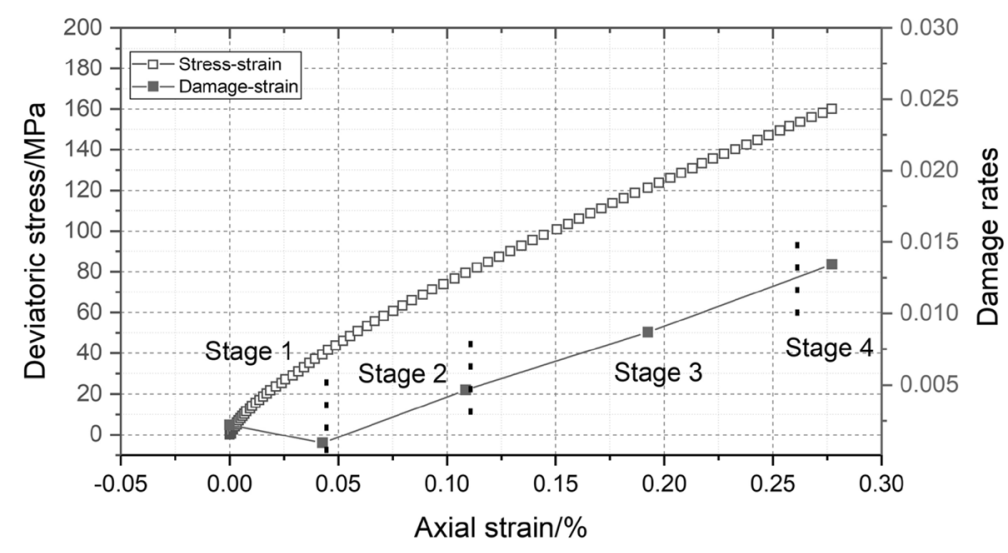

(c) Micro damage-strain and stress-strain curves of sample (distilled water)

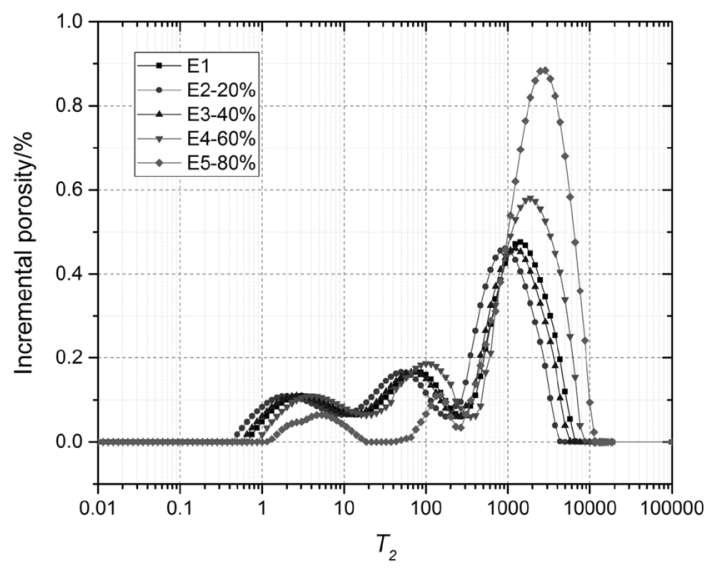

(d) $T_{2}$ distributions of the samples (pH3)

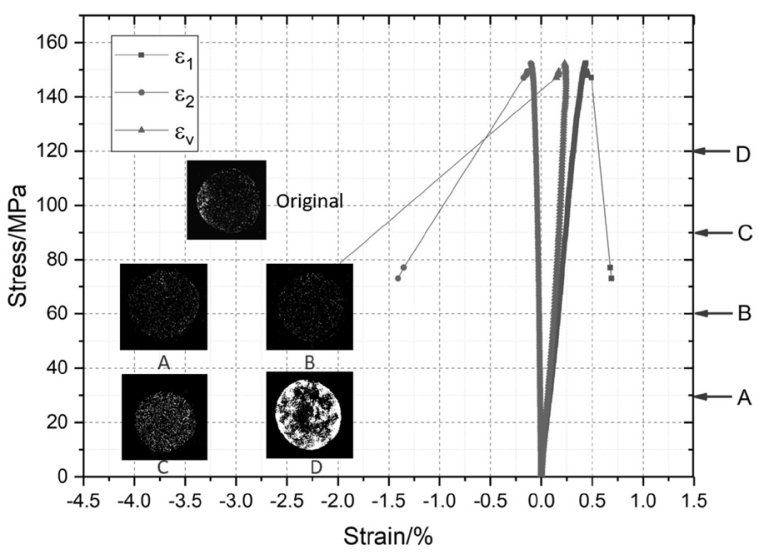

(e) stress-strain curves and MRI of the sample (pH3)

Fig. 7 MRI and micro damage evolution of the limestone samples under external stress (Li et al. 2018)

than in other groups, as presented before in this section. Thus, the degradations in peak strength of the chemical corroded samples under different unloading rates are higher than those in other groups. The smallest degradation is observed in samples softened by distilled water (Fig. 8). It can also be observed from Fig. 8, the peak strength decreased with the increasing unloading rates.
The fracturing pattern of chemically corroded samples as compared with water soften samples is given in Fig. 9. For better viewing, the images of the fracture patterns are also processed using Adobe Photoshop CS5 to emphasize the contrast. Irrespective of the extent of exposure to chemical conditions, the unloading failure mode tends to be a single planar shear fracture at high unloading rates 


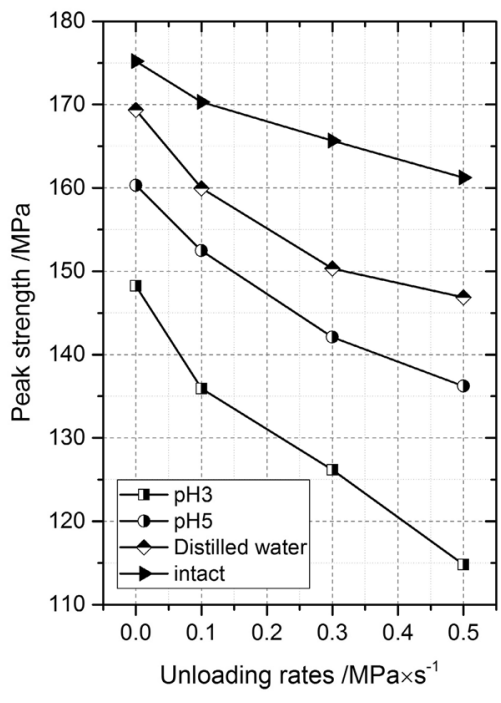

Fig. 8 Peak strength at different unloading rates

(Fig. 9c, f). When the unloading rate is low, the rock ruptures with some shear fractures accompanied by many tensile cracks along the shear fracture surface, (Fig. 9a, d). The failure mode of limestone is not only affected by unloading rates, but also chemical effects. For the chemically corroded sample ( $\mathrm{pH} 3)$, when the unloading rate is $0.01 \mathrm{MPa} \mathrm{s}^{-1}$ and $0.03 \mathrm{MPa} \mathrm{s}^{-1}$ (Fig. 9a, b) the sample exhibits a mixed tensile and shear fracturing mode. When the unloading rate is $0.05 \mathrm{MPa} \mathrm{s}^{-1}$, it is ruptured by a single shear fracture (Fig. 9c). For water-softened samples, when the unloading rate is $0.01 \mathrm{MPa} \mathrm{s}^{-1}$, multiple tensile and shear cracks contribute to its failure model (Fig. 9d). When the unloading rate is $0.03 \mathrm{MPa} \mathrm{s}^{-1}$ and $0.05 \mathrm{MPa} \mathrm{s}^{-1}$, the rock fails with a single shear fracture, which is a shear band with certain thickness (Fig. 9e, f).

The mechanical behavior of rock is influenced by micro structures, and confining pressure (You 2014). The failure development in rock initially consists of micro cracks closure, followed by micro cracks initiation and connection. Finally, macro crack occurs and connects resulting in sample rupture ( $\mathrm{Li}$ et al. 2018). Confining pressure unloading leads to an increase in tensile stress near the tip of micro cracks inside the rock samples and decrease in shear strength. Thus the potential of tensile and shear developments in rock increase (Huang and Huang 2014). With the increasing unloading rates of the confining pressure and chemical effects, stable crack development transforms relatively quickly into unstable crack development, degrading the peak strength of the limestone sample. Thus, the peak strength of the limestone sample decreased with the increasing unloading rates (Liu et al. 2017; Wang et al. 2011; Kaiser et al. 2001).

\section{Stress-Permeability (ESP) Model for Rocks Under HydroChemical-Mechanical Coupled Effects}

In this section, based on the data obtained from the mechanical and permeability test on limestone samples under coupled hydrochemical-mechanical conditions, the derivation process of the ESP model is initially presented. To analyze and verify the utility of the ESP model, theoretical results obtained from the ESP model as well as those from literature are then compared.

\subsection{Derivation of the ESP Model}

Figure 10 shows the relationship between stress and permeability for the chemically corroded samples ( $\mathrm{pH} 3$ ) at different unloading rates, the water-softened samples are also shown for comparison. Combining the conclusions of the damage developments obtained from the previous sections and Fig. 10, it is observed that the set of stress induced permeability curves also has three stages (described in Fig. 6) corresponding to the damage development stages of the chemical corroded samples under external stress. The three stages are defined by inflection and unloading points. The first part mainly consists of the compaction-induced permeability changes of the rock (Fig. 10), the second stage begins with an inflection point and represents the crack development-induced permeability and the third stage begins at the unloading points and ends when the sample ruptures.

Several mathematical methods were made to describe the relationship between external stress and mechanical behaviors associated with the corresponding micro structure changes (Jaeger et al. 2009). Some empirical equations were proposed, which were always based on power law (Kilmer et al. 1987), and can be expressed as follows (David et al. 1994):

$k=k_{0}\left(\frac{n}{n_{0}}\right)^{b}$,

where $k_{0}$ and $n_{0}$ are permeability and porosity of the original sample, respectively, and $b$ is a material constant named the porosity sensitivity exponent.

The limestone samples in our tests are mainly composed of calcspar, which can easily react with acid ions (e.g. $\mathrm{H}^{+}$), mainly resulting in increase in porosity. The reactions between calcspar and chemical ions occurring in the acidic solution can be expressed by Eqs. (10) and (11), proposed by Steefel and Van Cappellen (1990):

Rate $=A k\left(\Omega^{m}-1\right)^{n}$,

$\Omega=\frac{\text { IAP }}{K}$, 

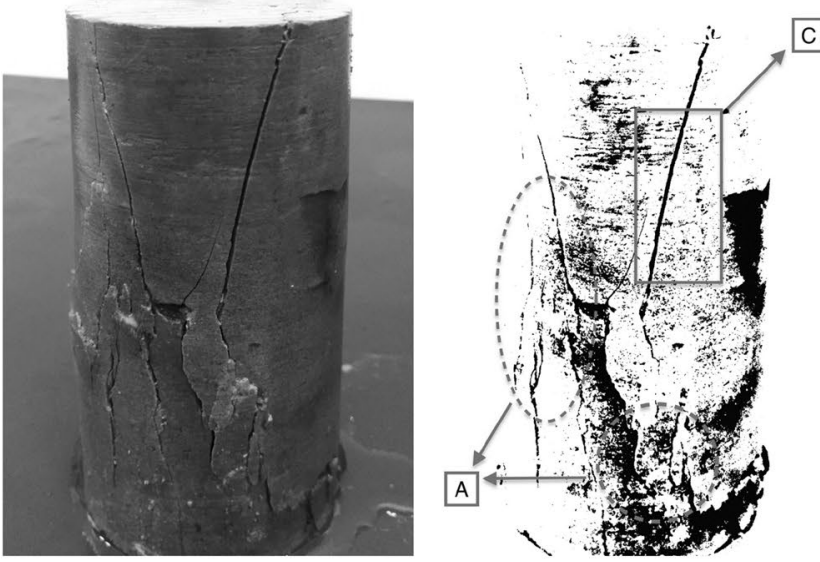

(a) $\mathrm{pH}=3$, unloading rates $=0.01 \mathrm{MPa} / \mathrm{s}$
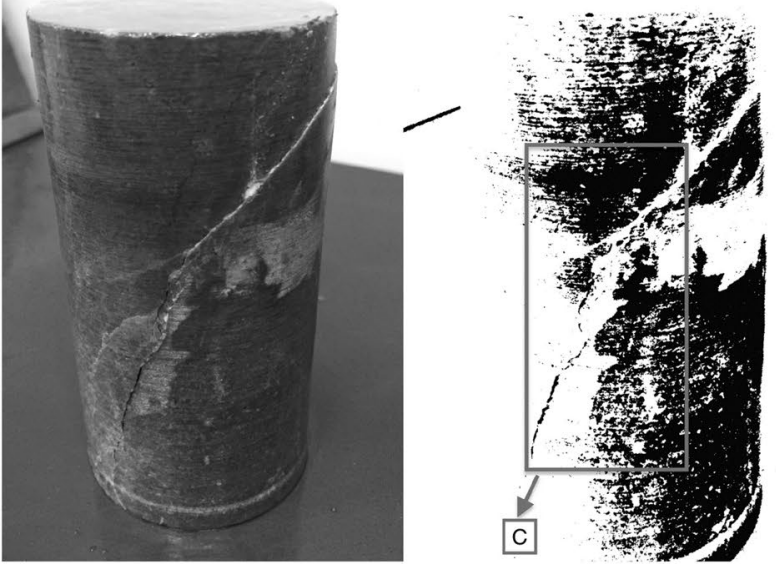

(c) $\mathrm{pH}=3$, unloading rates $=0.05 \mathrm{MPa} / \mathrm{s}$
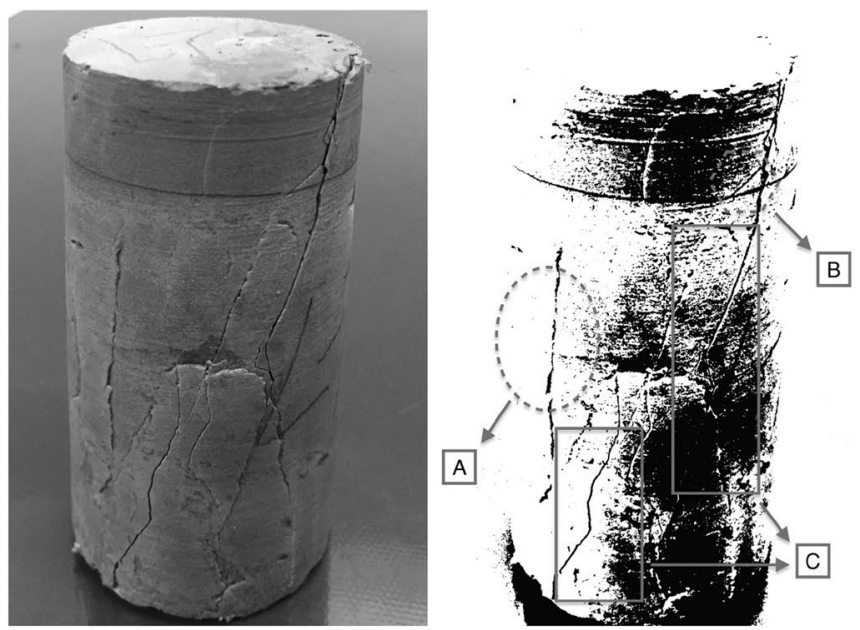

(b) $\mathrm{pH}=3$, unloading rates $=0.03 \mathrm{MPa} / \mathrm{s}$
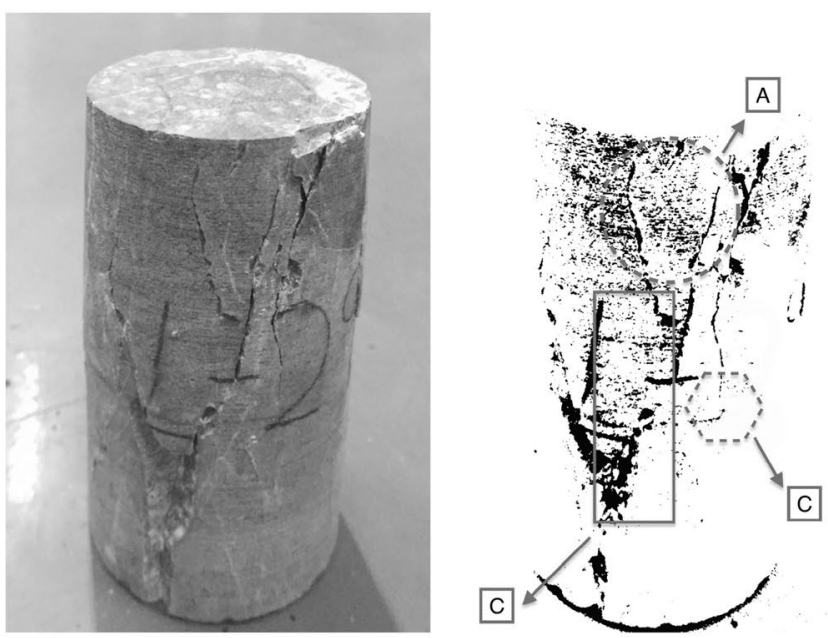

(d) Distilled water, unloading rates $=0.01 \mathrm{MPa}$
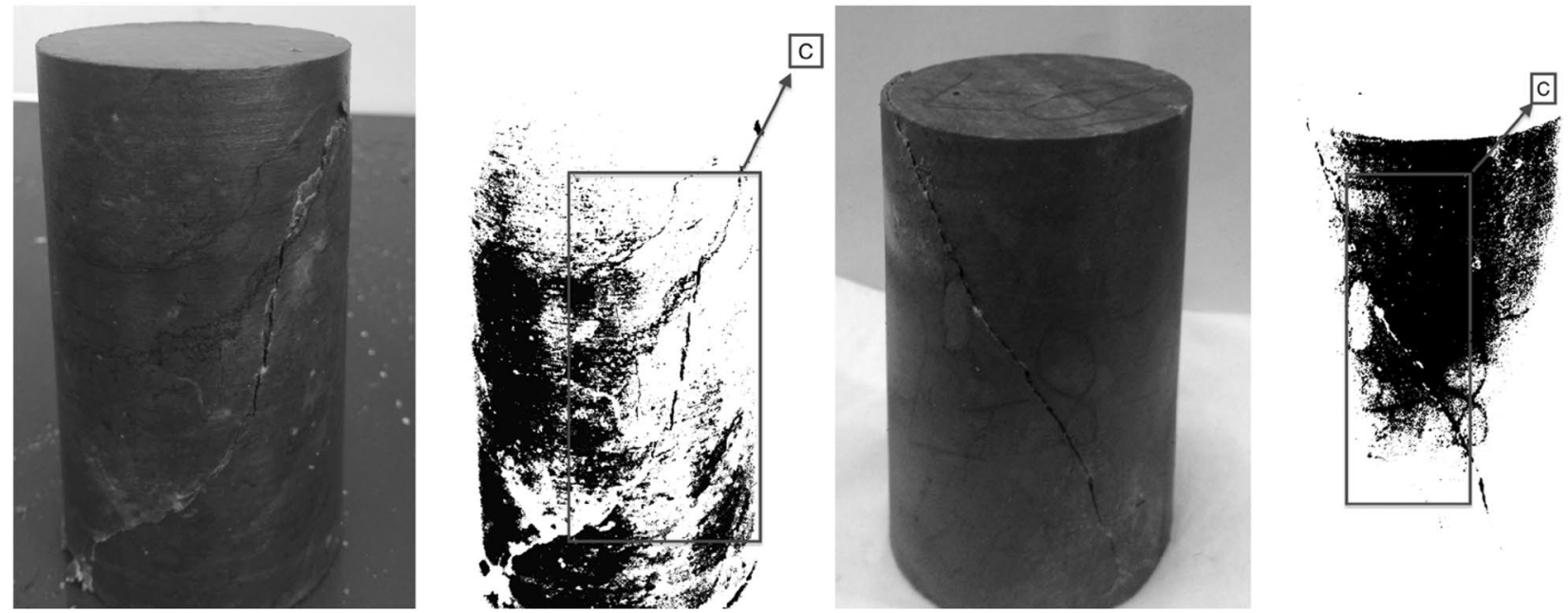

(e) Distilled water, unloading rates $=0.03 \mathrm{MPa}$

(f) Distilled water, unloading rates $=0.05 \mathrm{MPa}$

Fig. 9 Fracture modes of the chemical corroded and water-softened limestone samples under unloading condition (A: axial tensile cracks; B lateral tensile cracks; $\mathrm{C}$ shear cracks) 


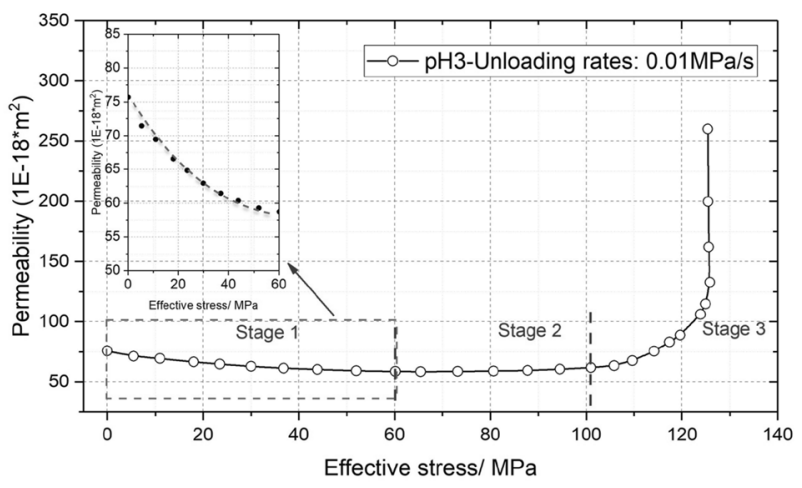

(a) Unloading rate $=0.01 \mathrm{MPa} / \mathrm{s}(\mathrm{pH} 3)$

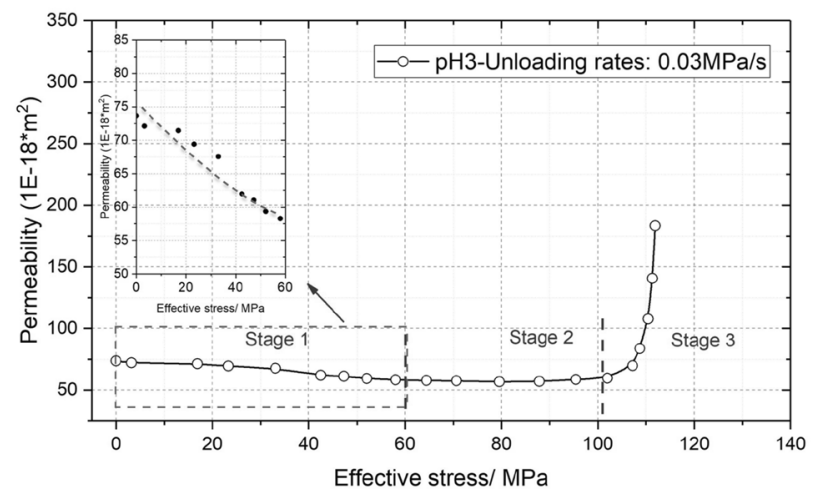

(c) Unloading rate $=0.03 \mathrm{MPa} / \mathrm{s}(\mathrm{pH} 3)$

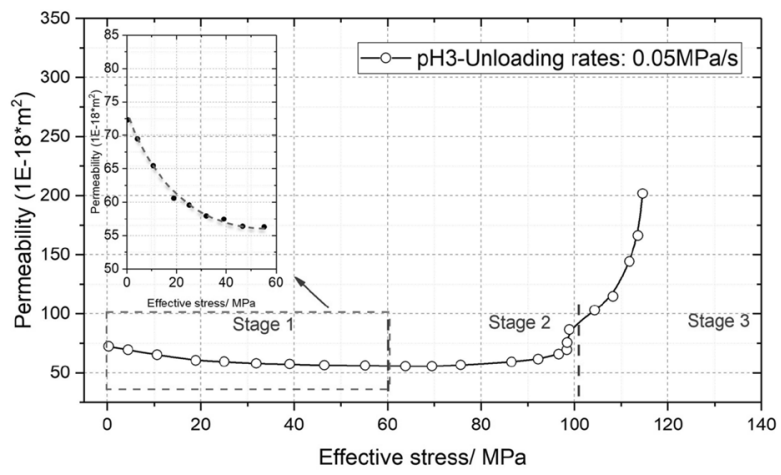

(e) Unloading rate $=0.03 \mathrm{MPa} / \mathrm{s}(\mathrm{pH} 3)$

Fig. 10 Stress vs permeability for the limestone samples

where Rate is the reaction rate of calcspar, $A$ is the reaction area of the sample, $k$ is the chemical reaction rate parameter, $K$ is the corresponding equilibrium constant, $\Omega$ is the solution saturation index, $m$ and $n$ are parameters, and IAP is the normalized saturation ratio, which is found that the effect of IAP on the overall behavior of the chemical reaction system is relatively small (Steefel and Van Cappellen 1990).

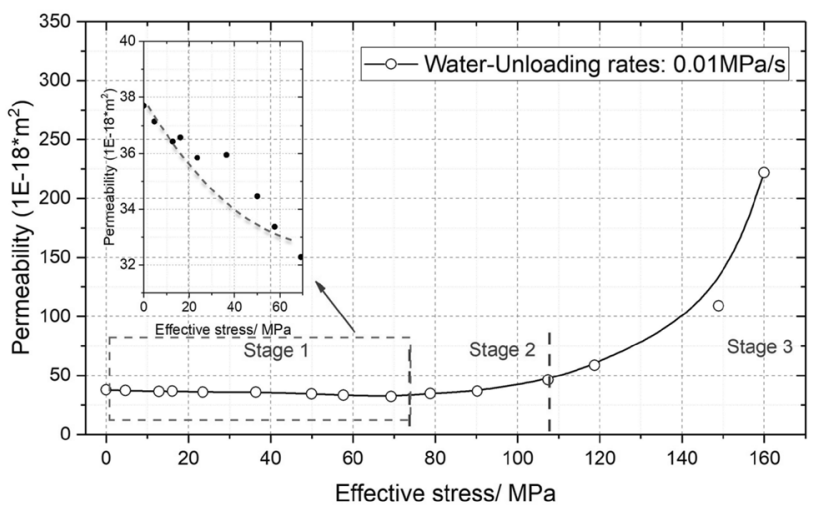

(b) Unloading rate $=0.01 \mathrm{MPa} / \mathrm{s}$ (Distilled water)

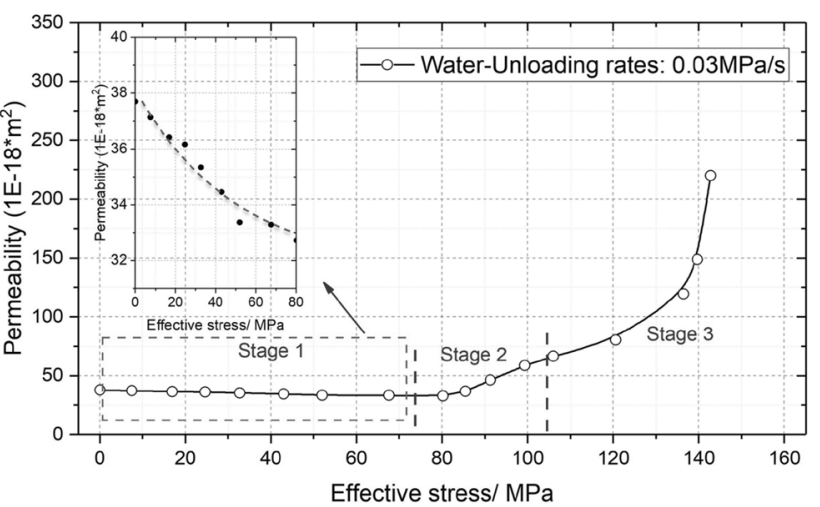

(d) Unloading rate $=0.01 \mathrm{MPa} / \mathrm{s}$ (Distilled water)

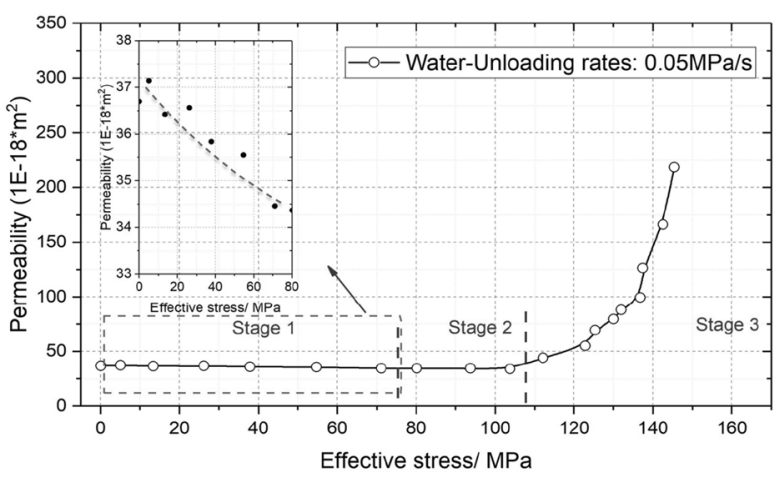

(f) Unloading rate $=0.05 \mathrm{MPa} / \mathrm{s}$ (Distilled water)

The density of calcspar in the limestone sample can be expressed as (Steefel and Van Cappellen 1990):

$\frac{\partial(1-n) p_{1}}{\partial t}=-\nabla\left(p_{1} n v\right)+p_{\mathrm{c}} V_{\mathrm{c}}$ Rate, 
where $n$ is the porosity of limestone, $p_{1}$ is the density of limestone, $p_{\mathrm{c}}$ is the density of calcspar, $V_{\mathrm{c}}$ is the molar volume of the calcspar, $v$ is the flow rates of chemical ions.

The porosity increment caused by chemical corrosion can be expressed as follows (Steefel and Van Cappellen 1990):

$\frac{\partial n_{c}}{\partial t}=r V_{\mathrm{c}}$ Rate,

where $r$ is the chemical reaction equivalent parameter, $V_{\mathrm{c}}$ is the molar volume of the calcspar, $t$ is the corrosion time, and $n_{\mathrm{c}}$ is the porosity caused by chemical reactions of calcspar.

Due to chemical corrosion, there is an increase in porosity of the rock, so that the permeability of the rock changes. From Eqs. (8) to (12), after chemical corrosion, the permeability $\left(k_{\mathrm{c}}\right)$ of the sample can be expressed as follows:

$k_{\mathrm{c}}=\left(\frac{\operatorname{tr} V_{\mathrm{c}} \text { Rate }}{n_{0}}\right)^{b} k_{0}$

Under external stress, the micro structure of the rocks could change, such as crack development. The compaction stage of the permeability model can be expressed by David et al. (1994):

$k=k_{0} \exp (-\alpha \sigma)$

where $k$ is the permeability at the effective stress $\sigma, k_{0}$ is the original permeability of the sample, and $a$ is the stress-sensitivity coefficient. Thus, after chemical corrosion, the permeability of the rock sample can be expressed as:

$k_{1}=k_{\mathrm{c}} \exp (-\alpha \sigma)=\left(\frac{\operatorname{tr} V_{\mathrm{c}} \text { Rate }}{n_{0}}\right)^{b} k_{0} \exp (-\alpha \sigma)$.

The second part of the ESP model is the development of micro cracks inside the rock sample under external stress, which can be fitted by Fig. 10 as follows:

$k_{2}=k_{1}+\beta_{1} \exp \left(-\sigma / w_{1}\right)$,

Thus, the ESP model can be expressed as follows:

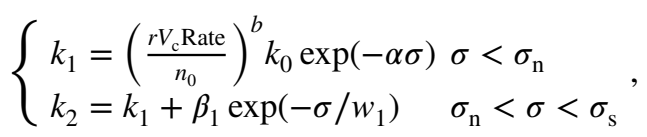

where $\sigma_{\mathrm{n}}$ is the transition point of stress for the micro cracks from the compaction stage to the development stage, which is about $30 \%$ of the peak strength of the rock sample; and $\sigma_{\mathrm{s}}$ is the peak stress.

Using data from both Li et al. (2018) and this study, the parameters of the ESP model can be obtained, as shown in Table 4.
Table 4 Parameters for the proposed ESP model for limestone

\begin{tabular}{lllll}
\hline $\begin{array}{l}\text { Reaction area } \\
\left(\mathrm{m}^{2} \mathrm{~g}^{-1}\right)\end{array}$ & Log $K$ & $m$ & $n$ & $\begin{array}{l}\text { Molar volume } \\
\text { of the calcspar } \\
\left(\mathrm{g} \mathrm{mol}^{-1}\right)\end{array}$ \\
\hline $7.07 \times 10^{-3}$ & 10.34 & 1 & 1 & 100 \\
$\mathrm{k} \mathrm{mol}^{-1} \mathrm{~m}^{2} \mathrm{~s}^{-1}$ & $\begin{array}{l}\text { Density of } \\
\text { calcspar/ } \\
\mathrm{kg} \mathrm{m} \mathrm{m}^{-3}\end{array}$ & $a$ & $b$ & \\
& 2650 & 0.112 & 0.001 & \\
$1.724 \times 10^{-6.8}$ & & & & \\
\hline
\end{tabular}

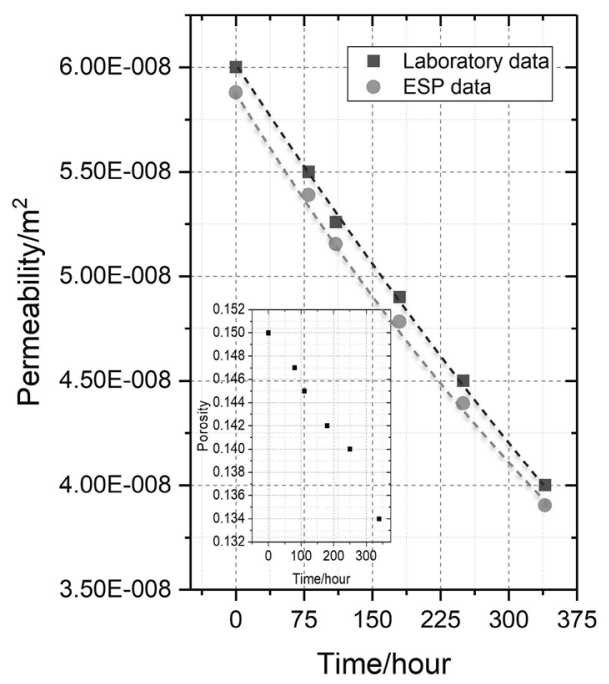

Fig. 11 Theoretical curve vs test data of the chemical corroded rock

\subsection{Verification and Prediction}

To validate the ESP model for sedimentary rocks, such as limestone in this study or sandstone, the permeability curve calculated by the model is compared with the laboratory test data in literature. Meanwhile, to find an appropriate experimental data, several criteria are taken into consideration: firstly, the test process is well documented, and the data is well presented. Secondly, the samples collected from construction sites surrounded by water are preferred, because they have it has more close relationships with underground water and can be better used in underground engineering applications. Thirdly, the porosity change is measured and presented. Last, the chemical solution is acid. After the chemical corrosion (solution $\mathrm{CaCl}_{2}, \mathrm{pH}$ 2), the porosity changes of the sample, theoretical results obtained from the ESP model, and that obtained from laboratory test are presented in Fig. 11. The parameters of the model can be fitted, as shown in Table 4. Since the chemical corroded samples in laboratory test were different, there is a slight difference between the theoretical results and that obtained from the laboratory test, and it can be concluded that this model 
Table 5 Parameters of ESP model

\begin{tabular}{|c|c|c|c|c|c|}
\hline $\mathrm{pH} 3-\beta_{1}$ & $\mathrm{pH} 3-w_{1}$ & $\mathrm{pH} 5-\beta_{1}$ & $\mathrm{pH} 7-w_{1}$ & Distilled water $-\beta_{1}$ & Distilled water $-w_{1}$ \\
\hline $1.38 \times 10^{-4}$ & -9.66 & $1.26 \times 10^{-4}$ & -9.34 & $0.9 \times 10^{-4}$ & -9.51 \\
\hline
\end{tabular}

can reflect the permeability changes of the rock (Fig. 11; Table 5).

\section{Conclusions}

NMR techniques are used to determine the $T_{2}$ values, porosity, MRI, permeability and mechanical characteristics of limestone samples under chemical effects. The effects of unloading rate and hydrochemical-mechanical coupled conditions on the mechanical behavior and the permeability of the corroded limestone are also explored, including the mechanism for permeability changes. Based on the experiments, the following conclusions are drawn:

1. In variance to the impact of constant confining pressure, the strength of limestone decreases under an unloading confining pressure. Under the same chemical damage rates, a higher rate of unloading confining pressure corresponds to a lower failure strength. For the same unloading rates, a higher chemical induced damage leads to higher degradation of mechanical properties.

2 . There are three stages of permeability evolution in limestone under unloading conditions: at the first stage, the permeability of limestone initially declines with increasing axial stress, then at the second stage the permeability increases slightly. At the third stage, the permeability of limestone increases dramatically until the sample is ruptured.

3. The development of micro cracks in limestone changes the rock permeability. The inflection point of the permeability curve is the threshold indicating a change from rock compaction to the development of micro cracks. Chemical corrosion and unloading rates have significant influence on the inflection point: the duration of the compaction stage of chemically corroded limestone samples experiencing slower unloading rates of confining pressure is more extensive in comparison to non-chemically corroded limestone samples and those exposed to faster unloading rates.

4. Based on the experimental results, an ESP model is established to describe the relationship between stress and permeability of the rock.

Acknowledgements The financial support from the Chinese Scholarship Council for Dr. Hao Li is gratefully acknowledged. The authors would also like to acknowledge Prof. Jie Yang and Dr. Kainan Xie's for their assistance with the NMR experiments. Special thanks are given to Dr. Peizhi Zhuang and Dr. Xiaohong Zhu for useful suggestions and discussion.

Open Access This article is distributed under the terms of the Creative Commons Attribution 4.0 International License (http://creativeco mmons.org/licenses/by/4.0/), which permits unrestricted use, distribution, and reproduction in any medium, provided you give appropriate credit to the original author(s) and the source, provide a link to the Creative Commons license, and indicate if changes were made.

\section{References}

Adushkin VV, Kocharyan GG, Ostapchuk AA (2016) Parameters determining the portion of energy radiated during dynamic unloading of a section of rock massif. Dokl Earth Sci 467:275-279

Alonso E, Zandarín M, Olivella S (2013) Joints in unsaturated rocks: thermo-hydro-mechanical formulation and constitutive behaviour. J Rock Mech Geotech Eng 5:200-213

Bouc O, Audigane P, Bellenfant G, Fabriol H, Gastine M, Rohmer J, Seyedi D (2009) Determining safety criteria for $\mathrm{CO}_{2}$ geological storage. Energy Procedia 1:2439-2446

Brady BH, Brown ET (2013) Rock mechanics: for underground mining. Springer, Berlin

Cantieni L, Anagnostou G (2009) The effect of the stress path on squeezing behavior in tunneling. Rock Mech Rock Eng 42:289-318

Cappa F, Rutqvist J (2011) Modeling of coupled deformation and permeability evolution during fault reactivation induced by deep underground injection of $\mathrm{CO}_{2}$. Int $\mathrm{J}$ Greenh Gas Control 5:336-346

Chai Z-Y, Kang T-H, Feng G-R (2014) Effect of aqueous solution chemistry on the swelling of clayey rock. Appl Clay Sci 93-94:12-16

Chen S-L, Feng X-T, Zhou H (2004) Study on triaxial meso-failure mechanism and damage variables of sandstone under chemical erosion. Rock Soil Mech Wuhan 25:1363-1367

Chen D, Pan Z, Ye Z, Hou B, Wang D, Yuan L (2016a) A unified permeability and effective stress relationship for porous and fractured reservoir rocks. J Nat Gas Sci Eng 29:401-412

Chen J, Jiang D, Ren S, Yang C (2016b) Comparison of the characteristics of rock salt exposed to loading and unloading of confining pressures. Acta Geotech 11:221-230

Croizé D, Bjørlykke K, Jahren J, Renard F (2010) Experimental mechanical and chemical compaction of carbonate sand. J Geophys Res Solid Earth. https://doi.org/10.1029/2010JB007697

Cui L, Fall M (2015) A coupled thermo-hydro-mechanical-chemical model for underground cemented tailings backfill. Tunn Undergr Space Technol 50:396-414

David C, Wong T-F, Zhu W, Zhang J (1994) Laboratory measurement of compaction-induced permeability change in porous rocks: implications for the generation and maintenance of pore pressure excess in the crust. Pure Appl Geophys 143:425-456

Feng X-T, Ding W (2007) Experimental study of limestone microfracturing under a coupled stress, fluid flow and changing chemical environment. Int J Rock Mech Min Sci 44:437-448 
Feng XT, Chen SL, Zhou H (2004) Real-time computerized tomography (CT) experiments on sandstone damage evolution during triaxial compression with chemical corrosion. Int J Rock Mech Min Sci 41:181-192

Friedman M (1975) Fracture in rock. Rev Geophys 13:352-358

Gaus I (2010) Role and impact of $\mathrm{CO}_{2}$-rock interactions during $\mathrm{CO}_{2}$ storage in sedimentary rocks. Int J Greenh Gas Control 4:73-89

Gaus I, Azaroual M, Czernichowski-Lauriol I (2005) Reactive transport modelling of the impact of $\mathrm{CO}_{2}$ injection on the clayey cap rock at Sleipner (North Sea). Chem Geol 217:319-337

Grgic D, Giraud A, Auvray C (2013) Impact of chemical weathering on micro/macro-mechanical properties of oolithic iron ore. Int $\mathbf{J}$ Rock Mech Min Sci 64:236-245

He M, Miao J, Feng J (2010) Rock burst process of limestone and its acoustic emission characteristics under true-triaxial unloading conditions. Int J Rock Mech Min Sci 47:286-298

Hu D, Zhou H, Hu Q, Shao J, Feng X, Xiao H (2012) A hydromechanical-chemical coupling model for geomaterial with both mechanical and chemical damages considered. Acta Mech Solida Sin 25:361-376

Huang R-Q, Huang D (2008) Experimental research on mechanical properties of granites under unloading condition. Chin J Rock Mech Eng 27:2205-2213

Huang RQ, Huang D (2014) Evolution of rock cracks under unloading condition. Rock Mech Rock Eng 47:453-466

Huang R, Wang X, Chan L (2001) Triaxial unloading test of rocks and its implication for rock burst. Bull Eng Geol Environ 60:37-41

Jaeger JC, Cook NG, Zimmerman R (2009) Fundamentals of rock mechanics. Wiley, New York

Jeffery PG, Hutchison D (1981) Chemical methods of rock analysis. Pergamon Press Ltd, New York

Ju Y, Wang Y, Su C, Zhang D, Ren Z (2019) Numerical analysis of the dynamic evolution of mining-induced stresses and fractures in multilayered rock strata using continuum-based discrete element methods. Int J Rock Mech Min Sci 113:191-210

Kachanov LM (1999) Rupture time under creep conditions. Int J Fract 97:11-18

Kaiser PK, Yazici S, Maloney S (2001) Mining-induced stress change and consequences of stress path on excavation stability-a case study. Int J Rock Mech Min Sci 38:167-180

Kawakata H, Cho A, Kiyama T, Yanagidani T, Kusunose K, Shimada M (1999) Three-dimensional observations of faulting process in Westerly granite under uniaxial and triaxial conditions by X-ray CT scan. Tectonophysics 313:293-305

Kilmer NH, Morrow NR, Pitman JK (1987) Pressure sensitivity of low permeability sandstones. J Petrol Sci Eng 1:65-81

Kirby SH (1984) Introduction and digest to the special issue on chemical effects of water on the deformation and strengths of rocks. J Geophys Res Solid Earth 89:3991-3995

Kruschwitz S, Yaramanci U (2004) Detection and characterization of the disturbed rock zone in claystone with the complex resistivity method. J Appl Geophys 57:63-79

Kwon O, Kronenberg AK, Gangi AF et al (2004) Permeability of illite-bearing shale: 1 . Anisotropy and effects of clay content and loading. J Geophys Res Solid Earth. https://doi.org/10.1029/2004J B003052

Lafrance N, Auvray C, Souley M, Labiouse V (2016) Impact of weathering on macro-mechanical properties of chalk: local pillar-scale study of two underground quarries in the Paris Basin. Eng Geol 213:107-119

Lasaga AC (1984) Chemical kinetics of water-rock interactions. J Geophys Res Solid Earth 89:4009-4025

Lemaitre J, Desmorat R (2005) Engineering damage mechanics: ductile, creep, fatigue and brittle failures. Springer, Berlin
Li Y, Tang D, Xu H, Meng Y, Li J (2014) Experimental research on coal permeability: the roles of effective stress and gas slippage. J Nat Gas Sci Eng 21:481-488

Li H, Zhong Z, Liu X, Sheng Y, Yang D (2018) Micro-damage evolution and macro-mechanical property degradation of limestone due to chemical effects. Int J Rock Mech Min Sci 110:257-265

Liu J, Li J (2011) Experimental research on sandstone pre-peak unloading process under high confining pressure. Chin J Rock Mech Eng 3:473-479

Liu H-H, Rutqvist J, Berryman JG (2009) On the relationship between stress and elastic strain for porous and fractured rock. Int J Rock Mech Min Sci 46:289-296

Liu Q, Cheng Y, Kan J, Tu Q, Wei Z, Rong Z (2017) Effect of confining pressure unloading on strength reduction of soft coal in borehole stability analysis. Environ Earth Sci 76:173

Martin C, Kaiser P, McCreath D (1999a) Hoek-Brown parameters for predicting the depth of brittle failure around tunnels. Can Geotech J 36:136-151

Martin CD, Kaiser PK, Tannant DD, Yazici S (1999b) Stress path and instability around mine openings. In: 9th ISRM congress. International Society for Rock Mechanics and Rock Engineering, Paris, France

Martin C, Kaiser P, Christiansson R (2003) Stress, instability and design of underground excavations. Int J Rock Mech Min Sci 40:1027-1047

Meng L, Li T, Xu J, Chen G, Ma H, Yin H (2012) Deformation and failure mechanism of phyllite under the effects of THM coupling and unloading. J Mt Sci 9(6):788-797

Moradian Z, Einstein HH, Ballivy G (2016) Detection of cracking levels in brittle rocks by parametric analysis of the acoustic emission signals. Rock Mech Rock Eng 49:785-800

Munoz H, Taheri A, Chanda EK (2016) Pre-peak and post-peak rock strain characteristics during uniaxial compression by 3D digital image correlation. Rock Mech Rock Eng 49:2541-2554

Qiu S, Feng X, Zhang C, Zhou H, Sun F (2010) Experimental research on mechanical properties of deep-buried marble under different unloading rates of confining pressures. Chin J Rock Mech Eng 29:1807-1817

Rohmer J, Pluymakers A, Renard F (2016) Mechano-chemical interactions in sedimentary rocks in the context of $\mathrm{CO}_{2}$ storage: weak acid, weak effects? Earth Sci Rev 157:86-110

Rutqvist J (2011) Status of the TOUGH-FLAC simulator and recent applications related to coupled fluid flow and crustal deformations. Comput Geosci 37:739-750

Rutqvist J, Tsang CF (2002) A study of caprock hydromechanical changes associated with $\mathrm{CO}_{2}$-injection into a brine formation. Environ Geol 42(2-3):296-305

Sato A, Obara Y (2017) Analysis of pore structure and water permeation property of a shale rock by means of X-ray CT. Procedia Eng 191:666-673

Seto M, Nag DK, Vutukuri VS, Katsuyama K (1997) Effect of chemical additives on the strength of sandstone. Int J Rock Mech Min Sci 34:280.e1-280.e11

Shalabi F (2005) FE analysis of time-dependent behavior of tunneling in squeezing ground using two different creep models. Tunn Undergr Space Technol 20:271-279

Sharifzadeh M, Tarifard A, Moridi MA (2013) Time-dependent behavior of tunnel lining in weak rock mass based on displacement back analysis method. Tunn Undergr Space Technol 38:348-356

Steefel CI, Van Cappellen P (1990) A new kinetic approach to modeling water-rock interaction: the role of nucleation, precursors, and Ostwald ripening. Geochim Cosmochim Acta 54(10):2657-2677

Sulem J, Lazar P, Vardoulakis I (2007) Thermo-poro-mechanical properties of clayey gouge and application to rapid fault shearing. Int J Numer Anal Methods Geomech 31:523-540 
Tsang C-F, Jing L, Stephansson O, Kautsky F (2005) The DECOVALEX III project: a summary of activities and lessons learned. Int J Rock Mech Min Sci 42:593-610

Vutukuri VS (1974) Handbook on mechanical properties of rocks. Int J Rock Mech Min Sci Geomech Abs 16(4):269

Wang Z-Q, Zhang L-M, Sun H, Zhang Y-H, Kuang S-YJR, Mechanics S (2011) Experimental study of mechanical properties of limestone under different unloading velocities. Rock Soil Mech 4:014

Westergaard HM (1952) Theory of elasticity and plasticity. Harvard University Press, Cambridge

Wibberley CAJ, Shimamoto T (2005) Earthquake slip weakening and asperities explained by thermal pressurization. Nature 436:689

Wojtacki K, Daridon L, Monerie Y (2017) Computing the elastic properties of sandstone submitted to progressive dissolution. Int J Rock Mech Min Sci 95:16-25

Wong LNY, Li D, Liu G (2013) Experimental studies on permeability of intact and singly jointed meta-sedimentary rocks under confining pressure. Rock Mech Rock Eng 46(1):107-121

Xie H, He C (2004) Study of the unloading characteristics of a rock mass using the triaxial test and damage mechanics. Int J Rock Mech Min Sci 41:74-80

Xue Y, Ranjith PG, Gao F, Zhang D, Cheng H, Chong Z, Hou P (2017) Mechanical behaviour and permeability evolution of gas-containing coal from unloading confining pressure tests. J Nat Gas Sci Eng 40:336-346

You M (2014) Effect of confining pressure on strength scattering of rock specimen. Chin J Rock Mech Eng 33:929-937
Zhang K, Zhou H, Pan P, Shen L, Feng X, Zhang Y-G (2010) Characteristics of strength of rocks under different unloading rates. Rock Soil Mech 31:2072-2078

Zhang K, Moridis G, Pruess K (2011) TOUGH $+\mathrm{CO}_{2}$ : a multiphase fluid-flow simulator for $\mathrm{CO}_{2}$ geologic sequestration in saline aquifers. Comput Geosci 37:714-723

Zhang R, Ning Z, Yang F, Wang X, Zhao H, Wang Q (2015) Impacts of nanopore structure and elastic properties on stress-dependent permeability of gas shales. J Nat Gas Sci Eng 26:1663-1672

Zhou K-P, Bin L, Li J-L, Deng H-W, Feng B (2015) Microscopic damage and dynamic mechanical properties of rock under freeze-thaw environment. Trans Nonferrous Met Soc China 25:1254-1261

Zhu W, Bruhns O (2008) Simulating excavation damaged zone around a circular opening under hydromechanical conditions. Int J Rock Mech Min Sci 45(5):815-830. https://doi.org/10.1016/j.ijrmm s.2007.09.007

Zou J, Chen W, Yang D, Yu H, Yuan J (2016) The impact of effective stress and gas slippage on coal permeability under cyclic loading. J Nat Gas Sci Eng 31:236-248

Publisher's Note Springer Nature remains neutral with regard to jurisdictional claims in published maps and institutional affiliations. 